\title{
15. NEW JERSEY COASTAL PLAIN OLIGOCENE SEQUENCES ${ }^{1}$
}

\author{
Stephen F. Pekar, ${ }^{2}$ Kenneth G. Miller, ${ }^{2,3}$ and James V. Browning ${ }^{2}$
}

\begin{abstract}
We evaluate Oligocene sequences recovered at three Leg 150X boreholes (Island Beach, Atlantic City, and Cape May, NJ) and their correlations to the $\delta^{18} \mathrm{O}$ proxy of glacioeustasy and the inferred eustatic record of Exxon. Sequence boundaries are identified by lithologic, gamma-ray log, and benthic foraminiferal changes and dated by integrated Sr-isotopic stratigraphy, biostratigraphy, and magnetostratigraphy. Three lower (O1, 32.8-32.2 Ma; O2, 30.8-29.9 Ma; and O3, 29.0-28.3 Ma) and three upper Oligocene sequences (O4, 27.5-27.0 Ma; O5, 27.0-25.6 Ma; and O6, 25.1-24.2 Ma) are described.

Hiatuses associated with six of seven Leg 150X Oligocene to earliest Miocene sequence boundaries correlate with major deep-sea $\delta^{18} \mathrm{O}$ increases: O1 with Oi1 (33.5 Ma) and Oila (32.8 Ma), O2 with Oilb (31.7 Ma), O3 approximately with Oi2 (30.0 Ma), O4 approximately with Oi2a (28.3 Ma), O5 with Oi2b (27.1 Ma), and Kw0 with Mi1 (23.7 Ma). The hiatus associated with the $\mathrm{O} 6$ sequence boundary may be correlated with a minor $\delta^{18} \mathrm{O}$ increase. The New Jersey Oligocene sequence boundaries also coincide with six Oligocene eustatic falls of Exxon. However, there are one (O4) or two (the Mays Landing unit at ACGS\#4 borehole) additional sequences in New Jersey that correlate with inferred glacioeustatic lowerings that are not shown in the Exxon synthesis. We conclude that the excellent correlation between inferred glacioeustatic lowerings $\left(\delta^{18} \mathrm{O}\right.$ increases) and sequence boundaries implies a causal link.

New Jersey Oligocene sequences are dominated by glauconite sands and silts. Transgressive Systems Tracts contain in situ glauconite, and Highstand Systems Tracts contain recycled glauconite. The sequence architecture in New Jersey is different between lower Oligocene (thin, Transgressive Systems Tract dominated, sediment starved) and upper Oligocene sequences (thick, Highstand Systems Tract dominated, clastic rich). This is may be due to higher amplitude early Oligocene sea-level changes or increased sediment supply in the late Oligocene.

Depositional centers during the early Oligocene were located south of Cape May and near Island Beach. However, the midOligocene ( 27 to $\sim 25 \mathrm{Ma}$ ) sequences at Cape May and at Island Beach are either thin or absent, whereas the sequences are thick at Atlantic City. This indicates that the depositional center shifted from near Cape May during the early Oligocene to near Atlantic City during the mid- and late Oligocene. These changes are probably the result of local tectonics and changes in sediment supply.
\end{abstract}

\section{INTRODUCTION}

Primary goals of the New Jersey Coastal Plain Drilling Project (Ocean Drilling Program [ODP] Leg 150X) were to recover and date Oligocene to Holocene sequences, to compare them to global deepsea $\delta^{18} \mathrm{O}$ records, and to evaluate sequence stratigraphic models (see Miller, Chapter 1, this volume for summary). Previous comparisons between the $\delta^{18} \mathrm{O}$ record and sequences have established a causal link between Miocene glacioeustatic lowerings and formation of sequence boundaries (Sugarman et al., 1993; Sugarman et al., 1995; Pekar et al., Chapter 8, this volume). Oligocene ice sheets are well documented (Miller et al., 1991; Zachos et al., 1994, 1996), and preliminary studies of Oligocene sections have suggested that sequence boundaries are linked to glacioeustatic lowerings (Miller et al., 1987, 1991; Pekar and Miller, 1996). However, Oligocene sediments are often absent in shallow-marine settings. In addition, Oligocene sections are difficult to date because of long biochrons and scarce biostratigraphic markers. With the advent of new dating techniques (e.g., Sr-isotopic stratigraphy) and continuously cored boreholes in the New Jersey Coastal Plain (e.g., Miller, et al., 1994, 1996a), Oligocene strata can now be studied in detail on a portion of the U.S. passive margin. Leg 150X was designed to drill boreholes updip, downdip, and along strike (Fig. 1), allowing evaluation of not only the ef-

${ }^{1}$ Miller, K.G., and Snyder, S.W. (Eds.), 1997. Proc. ODP, Sci. Results, 150X: College Station. TX (Ocean Drilling Program)

${ }^{2}$ Department of Geological Sciences, Rutgers University, Piscataway, NJ 08855 , U.S.A. spekar@ rci.rutgers.edu

${ }^{3}$ Lamont-Doherty Earth Observatory of Columbia University, Palisades, NY 10964, U.S.A. fects of glacioeustasy, but also the effects of local tectonics and sedimentation changes on the development of Oligocene sequences.

Understanding of Oligocene global sea-level (eustatic) changes has been hampered not only by problems in obtaining and dating shallow-marine sections, but also by problems in obtaining and interpreting deep-sea $\delta^{18} \mathrm{O}$ records. When Vail et al. (1977) first suggested a dramatic (hundreds of meters) mid-Oligocene sea-level lowering, most isotopic researchers believed the first Antarctic ice sheet did not form until the middle Miocene (e.g., Shackleton and Kennett, 1975). Glacioeustatic change is the only known mechanism for producing large, rapid sea-level change (Donovan and Jones, 1979), and it was not possible to reconcile large, rapid Oligocene sea-level changes with an ice-free world. Subsequent $\delta^{18} \mathrm{O}$ and Antarctic sediment studies have shown that East Antarctic ice began forming by at least the earliest Oligocene (e.g., Miller and Fairbanks, 1985; Miller et al., 1991; Zachos et al., 1994). However, East Antarctic ice-volume changes can explain only about 60-65 m of glacioeustasy (Shackleton and Opdyke, 1973), and even the revised "eustatic record" of Exxon (Haq et al., 1987) still shows a 130-m mid-Oligocene lowering.

Deep-sea $\delta^{18} \mathrm{O}$ records provide a firm chronology of inferred glacioeustatic changes. Miller et al. $(1987,1991)$ showed that intervals of high benthic foraminiferal $\delta^{18} \mathrm{O}$ values (>1.8\% in Cibicidoides) are incompatible with an ice-free world. Four such Oligocene-earliest Miocene benthic foraminiferal $\delta^{18} \mathrm{O}$ maxima were used to define oxygen isotopic Zones $\mathrm{O} 1, \mathrm{Oi} 2$, Oi2a, and Mi1; $\delta^{18} \mathrm{O}$ increases associated with these maxima are inferred glacioeustatic lowerings (Fig. 2; Miller et al., 1991). Although benthic foraminiferal $\delta^{18} \mathrm{O}$ records reflect both temperature changes and ice-volume fluctuations, Miller et al. (1991) used covariance between low-latitude planktonic and deep-sea benthic foraminiferal $\delta^{18} \mathrm{O}$ records as an indicator of ice- 
Figure 1. New Jersey base map showing the location of the three Leg 150X sites, Island Beach (1993), Atlantic City (1993), Cape May (1994). Also shown are Leggette, ACGS\#4, Jobs Point, and the Allaire boreholes used in construction of isopach maps. Outcrop belt is shown only for NJ.

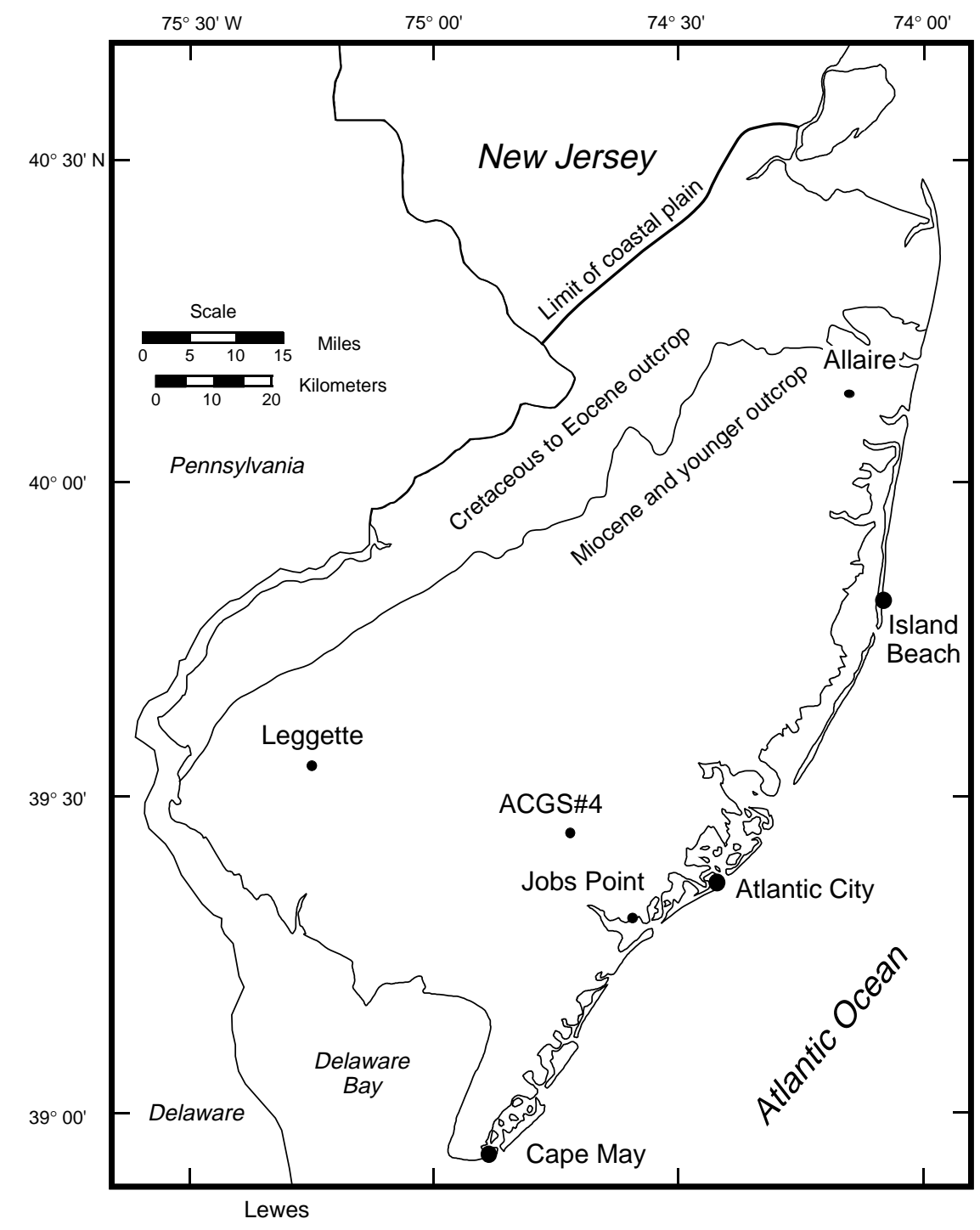

volume (glacioeustatic) changes. Thus, the eustatic signal embedded in deep-sea $\delta^{18} \mathrm{O}$ records can be determined, and the effects of glacioeustatic change on passive margin sequences can be evaluated.

The New Jersey Coastal Plain is characterized by generally quiescent Cenozoic tectonics resulting from thermal cooling and flexural loading (Steckler and Watts, 1981). However, it is clear that local tectonics (e.g., local faulting and flexural loading) have played an important role in shaping the Cenozoic record in this region (e.g., Brown et al., 1972; Benson, 1990, 1994; Owens et al., Chapter 2, this volume, and references therein). The effects of tectonics can be evaluated by comparing boreholes throughout the basin and by comparison with other basins. It is also clear that eustasy has shaped this margin (Olsson, 1991). We evaluate the effects of eustasy by comparing New Jersey Coastal Plain Oligocene sequences with the $\delta^{18} \mathrm{O}$ glacioeustatic proxy.

Owens and Sohl (1969) recognized that New Jersey Coastal Plain sediments contained transgressive/regressive successions. Olsson (1991) and Sugarman et al. (1993, 1995) recognized these as sequences and interpreted the facies in the context of sequence stratigraphy. However, these studies lacked detailed Oligocene sections.

Oligocene strata have not been identified in outcrops in New Jersey and were first recognized in the subsurface of New Jersey by Olsson et al. (1980), where they were dated as mid- to late Oligocene (Zones P20-P22). The distribution of Oligocene strata has remained uncertain until now, because core coverage and quality were not sufficient for delineating Oligocene sequences and facies in detail.

The first continuously cored borehole to recover Oligocene strata was drilled at Mays Landings in 1986 (ACGS\#4 borehole; Miller et al., 1990; 121-ft-thick [36.9 m] Oligocene section; Fig. 1). Recovery of the upper Oligocene section ( $90 \mathrm{ft}$ thick [27.4 m]) was extremely low ( $<5 \%$ recovery), and the preservation of calcareous microfossils was poor. The lower Oligocene $(31 \mathrm{ft}$ thick $[9.4 \mathrm{~m}])$ was dated by nannofossils (Poore and Bybell, 1988), the first time lowermost Oligocene strata were unequivocally identified from New Jersey. The overall poor recovery and preservation of the Oligocene section limited the study of foraminifers, the evaluation of sequences and their bounding unconformities, and the history of sea-level change along New Jersey during the Oligocene.

ODP Leg 150X drilled three onshore boreholes (Fig. 1) that recovered a total of $638 \mathrm{ft}$ (194.5 m) of Oligocene strata (Miller, et al., 1994, 1996a), allowing a detailed study of the New Jersey Oligocene for the first time. The Island Beach borehole, drilled in April 1993, contained $97 \mathrm{ft}(29.6 \mathrm{~m})$ of upper Oligocene and $95 \mathrm{ft}(29.0 \mathrm{~m})$ of lower Oligocene strata, with excellent core recovery and fair preservation of calcareous microfossils (Miller, et al., 1994). The Atlantic City borehole, drilled in June-August 1993, contained $204 \mathrm{ft}(62.2$ $\mathrm{m})$ of upper Oligocene and $63 \mathrm{ft}(19.2 \mathrm{~m})$ of lower Oligocene sediments (Miller, et al., 1994). Better preservation of the calcareous mi- 


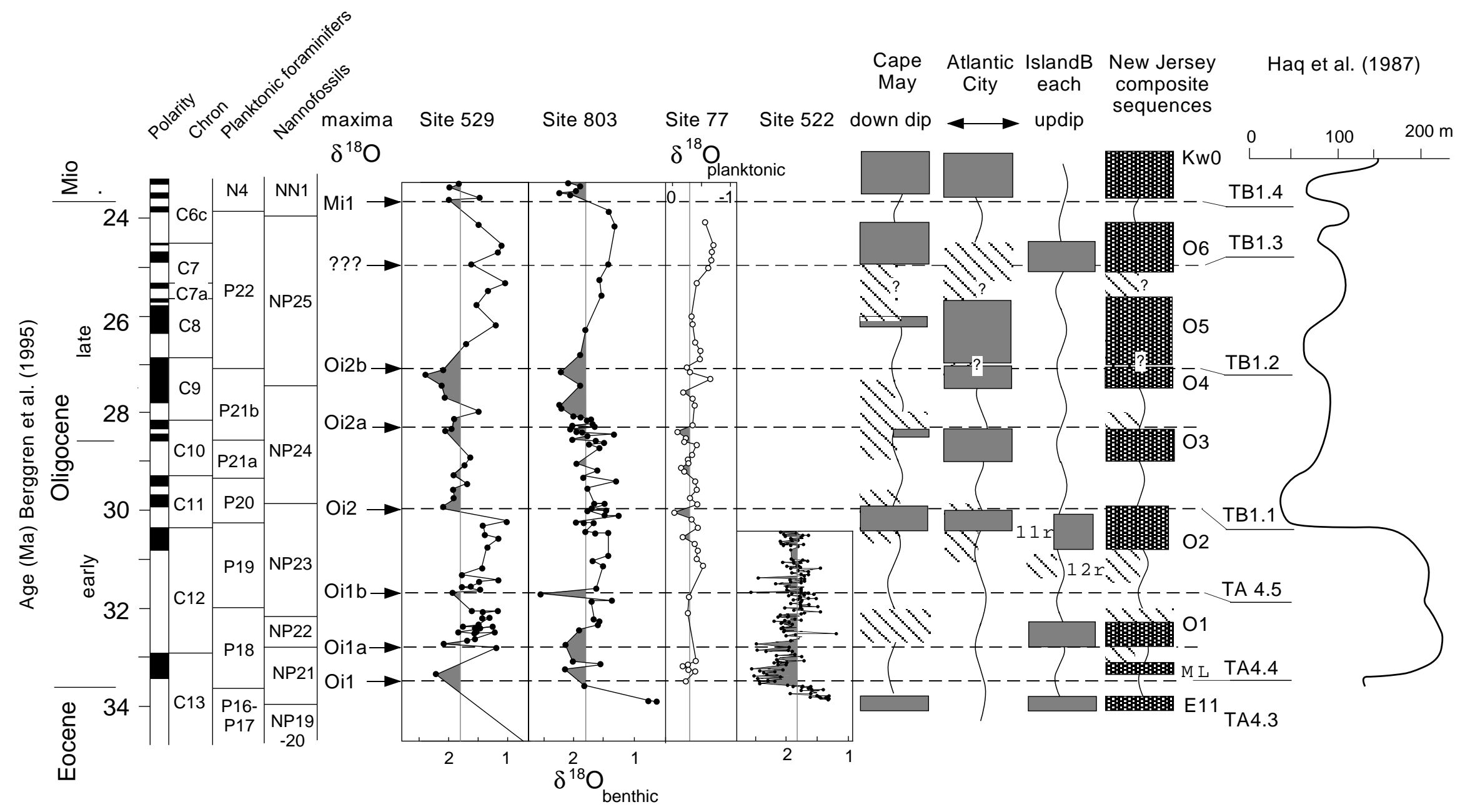

Figure 2. Ages of New Jersey Oligocene sequences compared to the benthic $\delta^{18} \mathrm{O}$ record at Sites 803 (Barrera et al., 1993) and 529 (Miller et al., 1991 ) and the planktonic $\delta^{18} \mathrm{O}$ record at Site 77 (Keigwin and Keller, 1984); open symbols). Oil through Mi1 are bases of oxygen-isotopic zones and are indicated with arrows; dashed lines indicate the inflections in the oxygen-isotopic increases associated with each zone. Boxes indicate time represented, white areas indicate hiatuses, cross-hatched areas indicate uncertain. $\mathrm{C} 12$ and $\mathrm{C} 11 \mathrm{r}$ are two possible interpretations for the $\mathrm{O} 2$ sequence at Island Beach (see text). The Haq et al. (1987) sequence and eustatic records are shown using the Berggren et al. (1995) time scale (see text). ML = Mays Landing unit, a possible earliest Oligocene sequence at the ACGS\#4 borehole (Owens et al., 1988). E11 = the youngest Eocene sequence represented at Island Beach and Cape May (Browning et al., Chapter 18, this volume). Kw0 = the oldest Miocene sequence represented at Atlantic City and Cape May (Miller et al., Chapter 14, this volume). 
Figure 3. Idealized lower Oligocene sequence and upper Oligocene sequence at New Jersey; their lithology and application of sequence stratigraphic terms are from Posamentier et al. (1988).

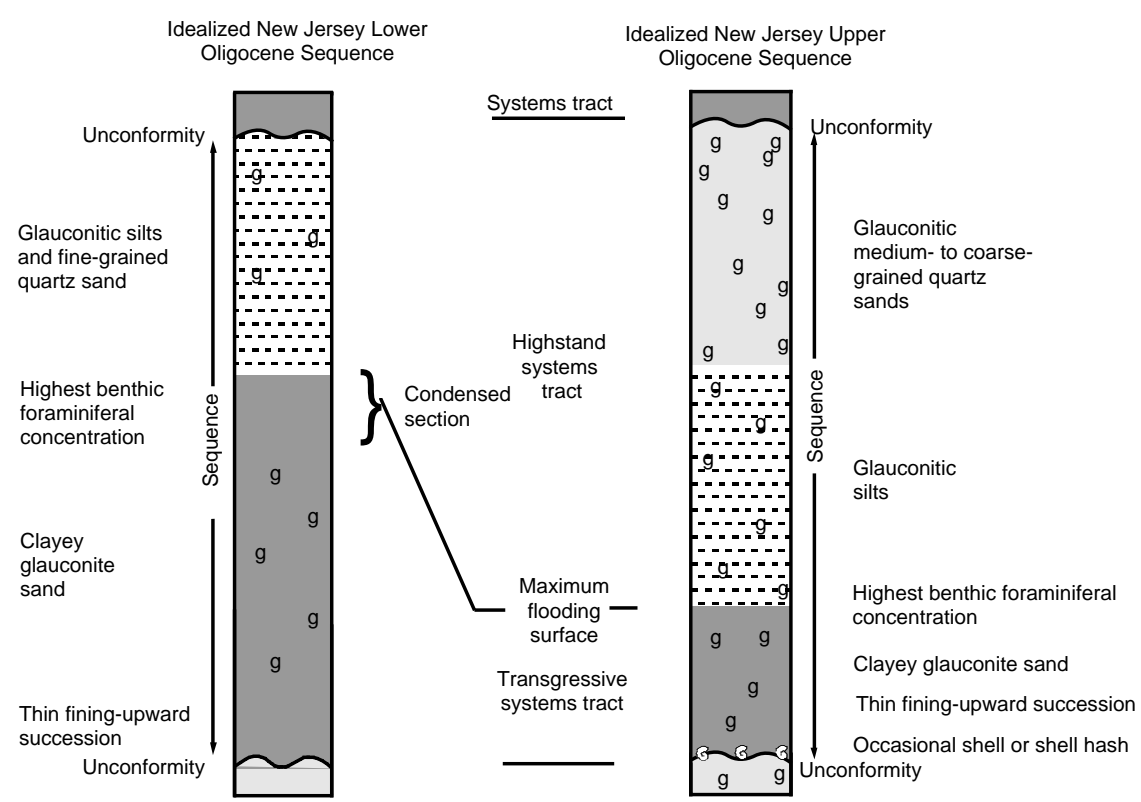

crofossils allowed evaluation of Oligocene benthic foraminifers. The Cape May borehole, drilled in March-April 1994, recovered $133.8 \mathrm{ft}$ $(40.8 \mathrm{~m})$ of upper Oligocene and $45 \mathrm{ft}(13.8 \mathrm{~m})$ of lower Oligocene strata with good recovery and preservation.

In this study, Oligocene sequences were delineated in the Atlantic City, Island Beach, and Cape May boreholes (Fig. 1). Unconformities (sequence boundaries) in the boreholes were recognized as surfaces with irregular contacts, reworking, bioturbation, and major facies changes (Fig. 3; Miller, et al., 1994, 1996a). Many of the unconformities are also associated with gamma-ray peaks. In addition, we were able to recognize additional unconformities and differentiate them from flooding surfaces by integrating the lithostratigraphy and changes in benthic biofacies assemblages. Sequences were dated by integrating biostratigraphy (Miller, et al., 1994, 1996a; Liu et al., Chapter 10, this volume), magnetostratigraphy (Van Fossen, Chapter 22, this volume), and Sr-isotopic stratigraphy (Miller, et al., 1994, 1996a; Pekar, 1995; this study). We divide sequences into systems tracts (Posamentier et al., 1988) and estimate water-depth variations using lithologic and benthic foraminiferal evidence. The New Jersey sequences are compared to the $\delta^{18} \mathrm{O}$ record and the inferred eustatic curve of Exxon (Haq et al., 1987) to test if eustasy has an important influence on the formation of sequences.

\section{METHODS}

Planktonic foraminiferal and nannofossil biostratigraphy are taken from Miller, et al. (1994, 1996a) and Liu et al. (Chapter 10, this volume). Sr-isotopic analyses provided by Miller, et al. (1994, 1996a) were supplemented by Pekar (1995) and this study. Magnetostratigraphy was successful in recognizing several Oligocene polarity zones at Island Beach (Van Fossen, Chapter 22, this volume). Together, these provide the primary age control on the boreholes.

Lithologic descriptions were provided by Miller, et al. (1994, 1996a) and Pekar (1995). In addition, we show cumulative percentage data of the medium-coarse quartz sand, fine quartz sand, siltclay, glauconite sand, and shell components (Figs. 4-6). The percentage of silt-clay was determined quantitatively from samples washed through a $63-\mu \mathrm{m}$ sieve for foraminiferal studies. In sections with glauconite, the abundances of other components were visually estimated from the greater than $63-\mu \mathrm{m}$-size fraction; in sections without glauconite and shell material, the percentages of fine vs. medium- coarse sand were obtained by dry sieving and weighing. Based on Leg $150 X$ results, Pekar et al. (Chapter 8 , this volume) recognize two new Oligocene lithologic units: the glauconitic silts with subordinate glauconite sands of the Sewell Point Formation below and quartz and glauconite sands of the Atlantic City Formation above (Figs. 4-6; see Pekar et al. [Chapter 8, this volume] for designation and discussion of these units).

Samples from the Island Beach, Atlantic City, and Cape May boreholes that were used for benthic foraminiferal studies were prepared using standard sampling and processing techniques (Pekar, 1995). Approximately 300 benthic foraminiferal specimens from the $>63-\mu \mathrm{m}$-size fraction were sorted and identified for quantitative analysis. Samples with abundant foraminifers were split using a micro-

Benthic foraminifers were identified using the taxonomy of Cushman and Cahill (1933), Toulmin (1941), Cushman and Stainforth (1945), Renz (1948), Loeblich and Tappan (1964), Smith (1964), Butt (1966), Schnitker (1970), Poag (1981), Boersma (1984), Lamb and Miller (1984), Wood et al. (1985), Van Morkhoven et al. (1986), and Benson (1990). Twenty-seven samples from Cape May and 22 samples from Atlantic City were analyzed quantitatively in this study. Percentage data were computed for samples with greater than 100 specimens, and Q-mode principal component and factor analyses were performed on the data set. We extracted ten principal components (eigenvalues $>1$ ) and rotated nine factors (80.3\% of the faunal variation explained). The high number of factors allowed a detailed division of the different benthic foraminiferal biofacies assemblages for each borehole. Biofacies were recognized using factor analysis and percentage data (factor scores and loadings are available from the authors by request). Paleobathymetries were determined for each assemblage from sedimentological data and by comparison to fossil and modern benthic foraminiferal habitat studies (Pekar, 1995).

Oligocene Sr-isotopic age estimates were obtained from 14 samples from Atlantic City, five samples from Island Beach, and 18 samples from Cape May (Table 1). Shell fragments from mollusks $(\sim 0.1$ $\left.\mathrm{cm}^{3}\right)$ or benthic foraminifers ( $\sim 70$ large specimens) were used for each analysis (Miller, et al., 1994, 1996a; Pekar, 1995). Sr-isotopic ages were calibrated to the Cande and Kent (1992) time scale using the regressions of Oslick et al. (1994). Otherwise, the Berggren et al. (1995) time scale is used throughout. The differences between the Cande and Kent (1992) and Berggren et al. (1995) Oligocene time scales are relatively minor ( $<0.1$ m.y.). Sr-isotopic regressions for the splitter to obtain totals close to 300 specimens. 


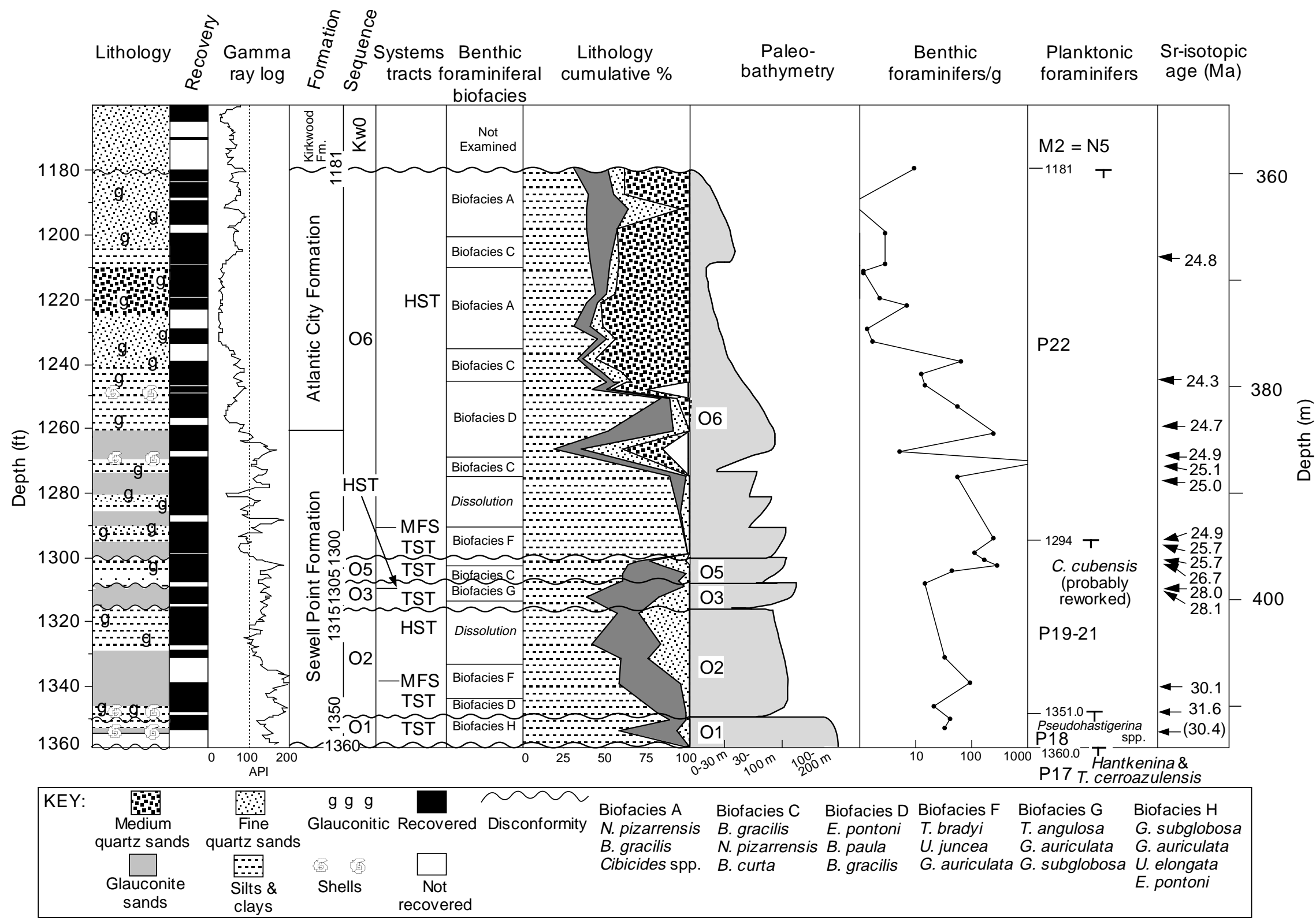

Figure 4. Cape May Oligocene stratigraphic column. Lithology is modified from Miller, et al. (1996a). Benthic foraminiferal biofacies and benthic foraminifers/gram are from Pekar (1995). Sr-isotopic age estimates are from Miller, et al. (1996a) and this study. Sequence stratigraphic terminology is based on Posamentier et al. (1988). Sr-isotopic value in parentheses is considered an outlier due to stratigraphic inversion. 


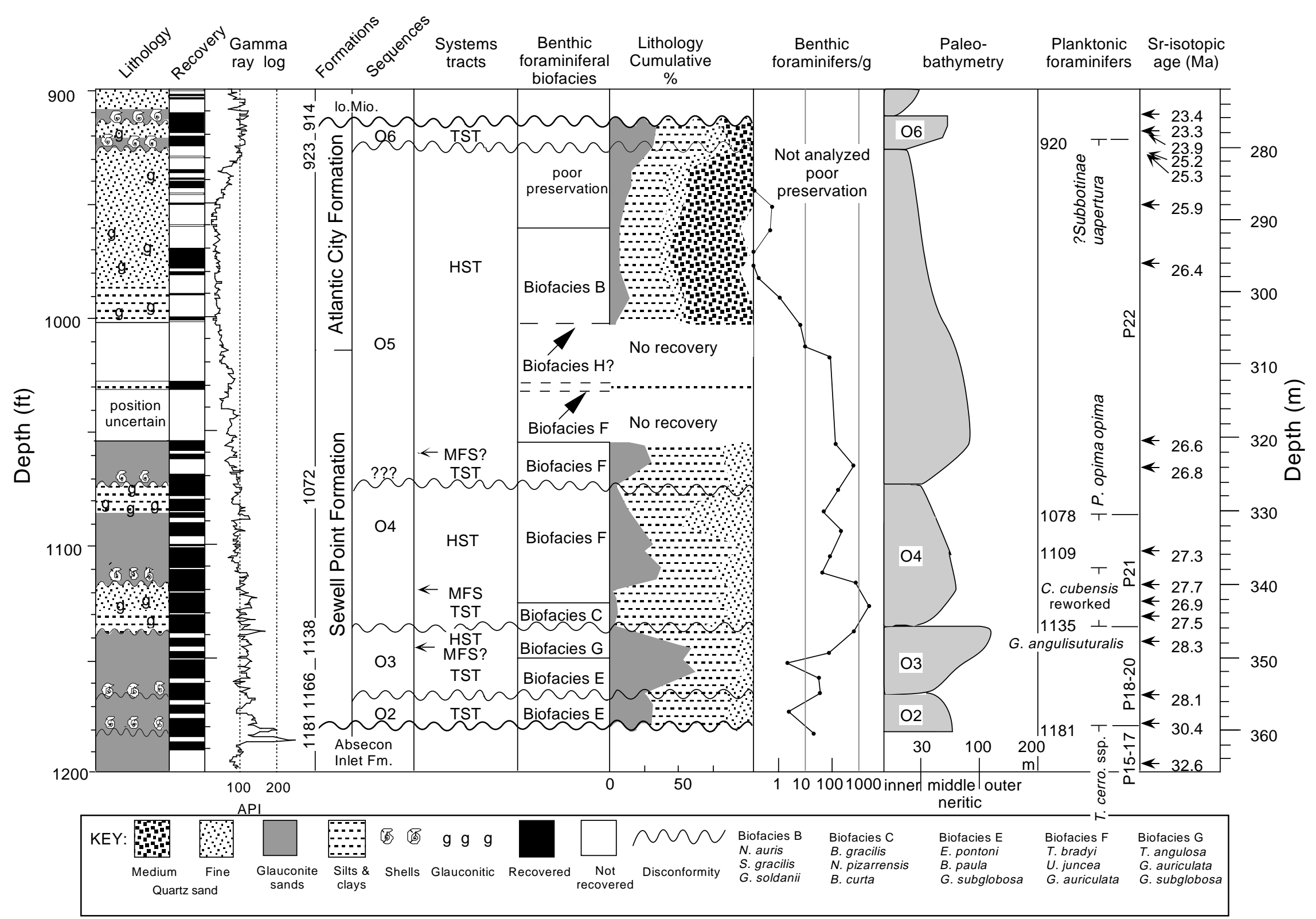




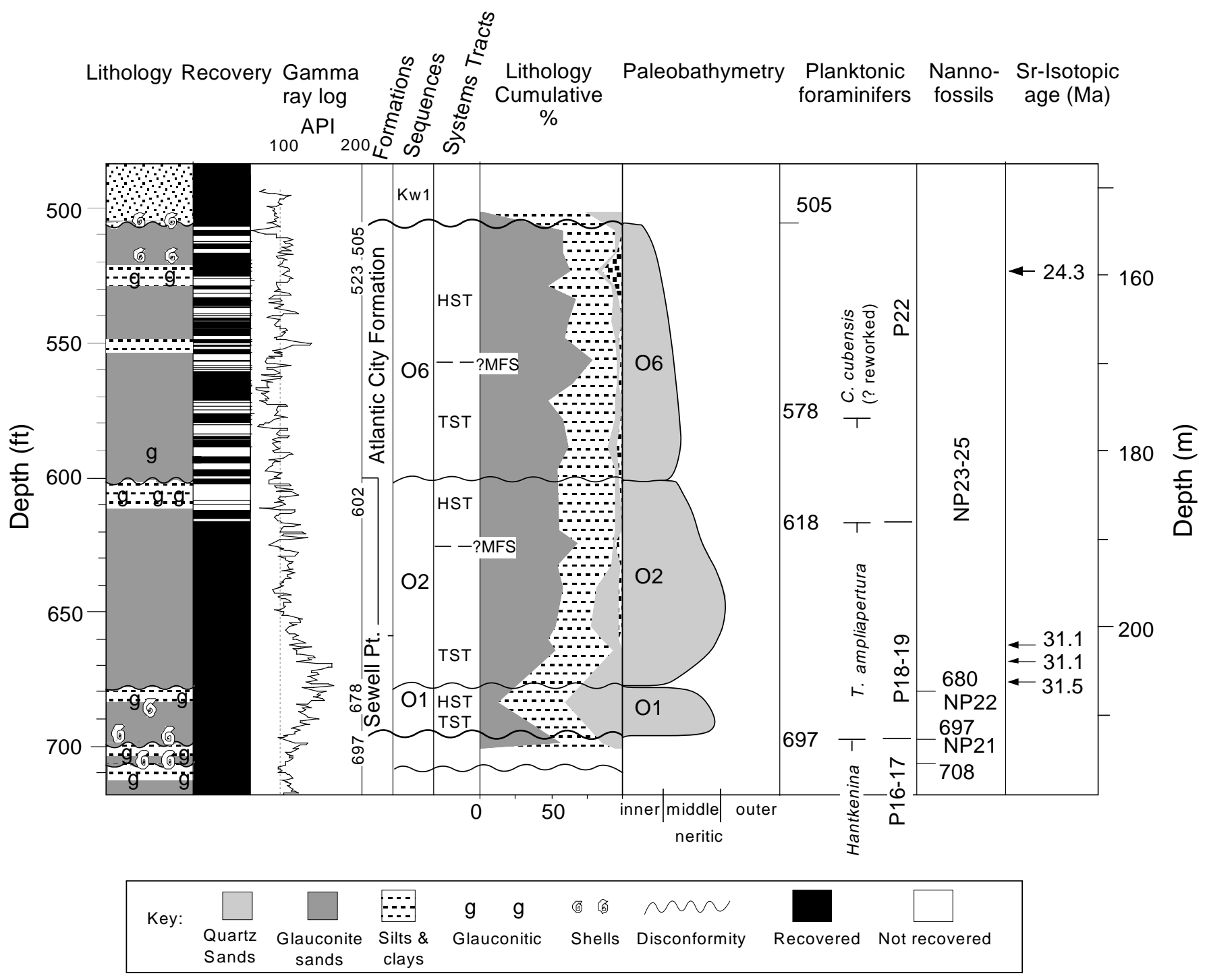

Figure 6. Island Beach Oligocene stratigraphic column. See Figure 4 caption for description.

late Oligocene have age uncertainties of approximately $\pm 0.8-1.0$ m.y. (Oslick et al., 1994) or better (as good as \pm 0.6 m.y.; Reilly et al., 1996), whereas early Oligocene regressions have uncertainties of \pm 1.0 m.y. (Miller et al., 1988) to \pm 0.7 m.y. (Reilly et al., 1996).

\section{RESULTS}

\section{New Jersey Oligocene Sequences}

New Jersey Oligocene strata can be divided into transgressive/ regressive sequences (Fig. 3). New Jersey Oligocene sequences are ideally characterized by a basal transgressive systems tract (TST) consisting of clayey glauconite sands overlain by a shallowingupward highstand systems tract (HST) of medial glauconite silts and upper glauconitic quartz sands (Fig. 3). Lowstand systems tracts (LSTs) have not been recognized. The maximum flooding surface (MFS) separating the TST from the HST (Posamentier et al., 1988) can be difficult to distinguish from lithology alone. Benthic foraminifers provide additional evidence for recognizing MFSs. The genus Uvigerina is often found in high abundance in the condensed sections associated with MFSs (Loutit et al., 1988), whereas benthic foraminiferal studies can be used to recognize the deepest water depths of a sequence. In addition, MFSs in Leg 150X Oligocene sequences are associated with the highest concentrations of benthic foraminifers per gram of sediment.

HSTs are generally typified by coarsening-upward successions. In the New Jersey Oligocene section, the HST deposits contain recycled glauconite. Recycling is indicated by (1) abraded, cracked grains; (2) the mixing of green glauconite and brown grains, with the brown grains weathered to goethite and an undifferentiated clay mineral; (3) the dominance of fine to coarse quartz sands, with glauconite constituting a secondary mineral; and (4) the association of the glauconite with inner neritic benthic foraminiferal taxa, indicating deposition in paleodepths less than $30 \mathrm{~m}$. Because glauconite only forms in quiescent, sediment starved, low-oxygen, middle neritic and deeper paleoenvironments (McRae, 1972), these grains cannot be in situ. This recycled glauconite yields high gamma-ray log values that mask the stratigraphic successions, making the identification of the sequence systems tracts difficult using well logs alone.

There are differences between the lower and upper Oligocene sequences (Fig. 3). Lower Oligocene sequences are usually thin and the TSTs dominate the sequences. The basal parts of sequences generally consist of sandy glauconitic clay-silts and fine-grained sand that rapidly grade into clayey glauconite sand, indicating rapid water deepening from inner middle neritic to middle neritic or deeper environments. Above this deepening-upward succession, dark green clayey 
Table 1. Sr-isotopic age estimates obtained from Oligocene samples taken from the three ODP Leg $150 \mathrm{X}$ boreholes.

\begin{tabular}{|c|c|c|c|c|c|}
\hline $\begin{array}{l}\text { Depth } \\
\text { (ft) }\end{array}$ & Material & ${ }^{87} \mathrm{Sr} /{ }^{86} \mathrm{Sr}$ & Error $( \pm)$ & $\begin{array}{l}\text { BKV age } \\
\text { (Ma) }\end{array}$ & $\begin{array}{c}\text { CK age } \\
\text { (Ma) }\end{array}$ \\
\hline \multicolumn{6}{|l|}{ Cape May } \\
\hline & $\mathrm{s}$ & 0.708290 & 0.000006 & 23.1 & 23.6 \\
\hline 1209.0 & $\mathrm{~s}$ & 0.708228 & 0.000014 & 25.0 & 24.8 \\
\hline 1209.0 & $\mathrm{~s}$ & 0.708229 & 0.000029 & 24.9 & 24.7 \\
\hline 1209.0 & $\mathrm{~s}$ & 0.708315 & 0.000019 & 22.5 & 23.1 \\
\hline 1247.0 & $\mathrm{~s}$ & 0.708257 & 0.000006 & 24.1 & 24.2 \\
\hline 1249.0 & s & 0.708251 & 0.000011 & 24.3 & 24.3 \\
\hline 1261.0 & $\mathrm{~s}$ & 0.708229 & 0.000018 & 24.9 & 24.7 \\
\hline 1268.0 & $\mathrm{~s}$ & 0.708335 & 0.000038 & 21.9 & 22.7 \\
\hline 1271.0 & $\mathrm{f}$ & 0.708222 & 0.000008 & 25.1 & 24.9 \\
\hline 1271.9 & f & 0.708212 & 0.000008 & 25.4 & 25.1 \\
\hline 1275.9 & f & 0.708218 & 0.000008 & 25.3 & 25.0 \\
\hline 1299.0 & $\mathrm{f}$ & 0.708223 & 0.000014 & 25.1 & 24.9 \\
\hline 1300.0 & $\mathrm{f}$ & 0.708181 & 0.000020 & 26.3 & 25.7 \\
\hline 1302.0 & $\mathrm{f}$ & 0.708178 & 0.000006 & 26.4 & 25.7 \\
\hline 1303.8 & $\mathrm{f}$ & 0.708131 & 0.000008 & 27.8 & 26.7 \\
\hline 1305.8 & f & 0.708063 & 0.000055 & 29.7 & 28.0 \\
\hline 1308.8 & $\mathrm{~s}$ & 0.708055 & 0.000030 & 29.9 & 28.1 \\
\hline 1340.0 & $\mathrm{f}$ & 0.708034 & 0.000013 & 30.6 & 28.5 \\
\hline 1340.0 & $\mathrm{f}$ & 0.707995 & 0.000030 & 31.7 & 30.1 \\
\hline 1340.0 & f & 0.707998 & 0.000008 & 31.6 & 30.0 \\
\hline 1350.0 & s & 0.707939 & 0.000008 & 33.3 & 31.6 \\
\hline 1350.0 & $\mathrm{~s}$ & 0.70794 & 0.000031 & 33.3 & 31.6 \\
\hline 1354.0 & $\mathrm{~s}$ & 0.707973 & 0.000020 & 32.3 & 30.7 \\
\hline \multicolumn{6}{|c|}{ Atlantic City } \\
\hline 913.0 & $\mathrm{~s}$ & 0.708303 & 0.000011 & 22.8 & 23.3 \\
\hline 913.0 & $\mathrm{~s}$ & 0.708273 & 0.000011 & 23.7 & 23.9 \\
\hline 917.5 & f & 0.708154 & 0.000038 & 27.1 & 26.2 \\
\hline 922.5 & $\mathrm{~s}$ & 0.708207 & 0.000026 & 25.6 & 25.2 \\
\hline 923.0 & s & 0.708199 & 0.000013 & 25.8 & 25.3 \\
\hline 948.0 & $\mathrm{~s}$ & 0.708172 & 0.000007 & 26.6 & 25.9 \\
\hline 974.5 & $\mathrm{~s}$ & 0.708142 & 0.000011 & 27.4 & 26.4 \\
\hline 974.5 & s & 0.708147 & 0.000012 & 27.3 & 26.3 \\
\hline 1056.0 & $\mathrm{~s}$ & 0.708135 & 0.000013 & 27.6 & 26.6 \\
\hline 1072.0 & $\mathrm{~s}$ & 0.708121 & 0.000011 & 28.1 & 26.8 \\
\hline 1117.0 & s & 0.708097 & 0.000014 & $\begin{array}{l}28.1 \\
28.7\end{array}$ & 27.3 \\
\hline 1122.8 & $\mathrm{~s}$ & 0.708075 & 0.000014 & 29.4 & 27.7 \\
\hline 1124.0 & $\mathrm{f}$ & 0.708117 & 0.000006 & 28.2 & 26.9 \\
\hline 1135.0 & $\mathrm{f}$ & 0.708087 & 0.000008 & 29.0 & 27.5 \\
\hline 1141.0 & $\mathrm{~s}$ & 0.708048 & 0.000007 & 30.2 & 28.3 \\
\hline 1164.5 & $\mathrm{~s}$ & 0.708056 & 0.000008 & 29.9 & 28.1 \\
\hline 1178.2 & s & 0.707936 & 0.000008 & 33.4 & 30.4 \\
\hline 1204.1 & $\mathrm{~s}$ & 0.707823 & 0.000013 & 36.6 & 32.6 \\
\hline 1301.1 & $\mathrm{~s}$ & 0.707784 & 0.000013 & 37.7 & 33.4 \\
\hline 1335.0 & $\mathrm{~s}$ & 0.707763 & 0.000007 & 38.3 & 33.8 \\
\hline \multicolumn{6}{|c|}{ Island Beach } \\
\hline 503.3 & $\mathrm{~s}$ & 0.708390 & 0.000015 & 21.7 & 21.4 \\
\hline 504.5 & $\mathrm{~s}$ & 0.708379 & 0.000004 & 21.8 & 21.6 \\
\hline 522.5 & $\mathrm{~s}$ & 0.708252 & 0.000005 & 24.3 & 24.3 \\
\hline 663.8 & $\mathrm{~s}$ & 0.707958 & 0.000006 & 32.7 & 31.1 \\
\hline 668.0 & $\mathrm{~s}$ & 0.707957 & 0.000012 & 32.8 & 31.1 \\
\hline 677.0 & s & 0.707944 & 0.000014 & 33.1 & 31.5 \\
\hline 683.6 & s & 0.707983 & 0.000006 & 32.0 & 30.4 \\
\hline 703.0 & s & 0.707743 & 0.000034 & 38.9 & 37.0 \\
\hline
\end{tabular}

Note: $\mathrm{s}=$ shell material, $\mathrm{f}=$ foraminifers .

in situ glauconite sand dominates the TST. The HSTs are often thin and appear to be truncated (upper HST quartz sand facies are absent), and consist of clayey glauconite sand near the base grading-upward to glauconitic silt and fine glauconitic quartz sand (Fig. 3).

In upper Oligocene sequences, the TSTs are thin and the HSTs are dominant (Fig. 3). The TSTs generally consist of glauconitic clays and silts. These are overlain by coarsening-upward successions consisting of glauconitic silts and glauconitic fine-grained quartz sands (lower HST) to glauconitic medium- to coarse-grained quartz sands (upper HST; Fig. 3). Thick glauconite sand facies observed in the lower Oligocene TSTs are typically absent in the upper Oligocene TSTs.

\section{Oligocene Depositional Sequences at Atlantic City, Cape May, and Island Beach}

Sequences, their bounding unconformities, and systems tracts are identified and dated for the Oligocene sections for each of the three boreholes. Physical stratigraphy (i.e., lithology, evidence of erosion) and benthic foraminiferal biofacies changes indicate that these surfaces represent significant downward shifts in baselevel. Most unconformities have resolvable ( $1 \mathrm{~m} . \mathrm{y}$. or longer) hiatuses (i.e., the bases of Sequences O1, O2, O3). Several inferred unconformities have shorter hiatuses ( 0.8 m.y.) that are not within the resolution of Sr-isotopic stratigraphy but are resolvable by integrating biostratigraphy and magnetostratigraphy. There is no resolvable hiatus associated with the base of Sequence O5 at Atlantic City.

The Cape May Oligocene section (1360-1181 ft [414.5-360.0 $\mathrm{m}]$ ) is divided into five sequences (Fig. 4). The lower Oligocene (1360-1304.8 ft [414.5-397.7 m]) contains three sequences (O1O3), and the upper Oligocene (1304.8-1181 ft [397.7-360.0 m], Fig. 4) contains two probable sequences $(\mathrm{O} 5, \mathrm{O} 6)$. The placement of the lower/upper Oligocene boundary is complicated. Planktonic foraminiferal studies indicate that the boundary is associated with a stratal surface at $1270 \mathrm{ft}$ (387.1 m; Miller, et al., 1996a; Liu et al., Chapter 10, this volume). A single specimen of Turborotalia ampliapertura at $1275 \mathrm{ft}(388.7 \mathrm{~m})$ above a $20-\mathrm{ft}(6.1 \mathrm{~m})$ dissolution zone and specimens of $C$. cubensis may indicate that the section below $1270 \mathrm{ft}$ ( $387.1 \mathrm{~m}$; Liu et al., Chapter 10, this volume) is lower Oligocene (Miller, et al., 1996a). In contrast, dinoflagellate cysts (de Verteuil, Chapter 11, this volume) and nannofossils indicate that the interval from 1270 to $1300 \mathrm{ft}(387.1-396.2 \mathrm{~m})$ is upper Oligocene. Sr-isotopic studies indicate that the lower/upper Oligocene boundary is between 1303.8 and $1305.8 \mathrm{Ma}(26.7$ and 28.1 Ma). Based on four Sr-isotopic analyses and dinocyst data, we place the lower/upper Oligocene boundary at the lower level and interpret occurrences of Chiloguembelina cubensis and T. ampliapertura above $1303.8 \mathrm{ft}$ as having been reworked.

The Atlantic City Oligocene section is divided into five thin sequences (Fig. 5). Two sequences are identified for the lower Oligocene $(\mathrm{O} 2, \mathrm{O} 3 ; 1181-1138 \mathrm{ft}$ [360.0-346.9 m]) and three probable sequences are identified within the upper Oligocene (O4-O6; 1138 $914 \mathrm{ft}$ [346.9-278.6 m]).

The Island Beach borehole is the most updip Leg 150X site (Fig. 1; Miller, et al., 1994). Three Island Beach Oligocene sequences were identified, two in the lower Oligocene (O1, O2; 697-602 ft [212.4$183.5 \mathrm{~m}])$ and at least one sequence in the upper Oligocene (O6; 602 $505 \mathrm{ft}$ [183.0-153.9 m]; Fig. 6). Sequences are more difficult to identify in Island Beach Oligocene strata than at the other Leg 150X sections because of poor preservation of calcareous fossils. However, gamma-ray logs provided a means to correlate the Cape May and Island Beach Oligocene strata, providing tentative placement of several sequence boundaries (Pekar, 1995). Used alone, gamma-ray logs would not provide the necessary data for placement of the Oligocene sequence boundaries within the Island Beach core, due to the glauconite gamma-ray signal (see above). However, the excellent stratigraphic record at Cape May provided a stratigraphic template for the New Jersey Oligocene strata, allowing gamma-ray log correlation with the Oligocene section at Island Beach.

\section{Chronology of the New Jersey Oligocene}

\section{Introduction}

We evaluate the ages of the sequences at Cape May (Fig. 7), Atlantic City (Fig. 8), and Island Beach (Fig. 9) using age-depth diagrams. Sr-isotopic ages are shown using conservative error estimates of $\pm 0.8 \mathrm{~m}$.y. Ages of the sequences are also constrained using the lowest and highest occurrence of planktonic foraminifers (Liu et al., Chapter 10, this volume) and sparse nannofossil zones (Miller, et al., 1994, 1996a). Because of environmental restriction, planktonic foraminiferal lowest occurrences (LOs) are often delayed (e.g., Paragloborotalia opima opima and Globigerina angulisuturalis, Fig. 8) and the highest occurrences (HOs) are often premature (e.g., Turborotalia ampliapertura, Fig. 9). In addition, the HO of Chiloguembelina cubensis is affected by reworking, although the highest consis- 


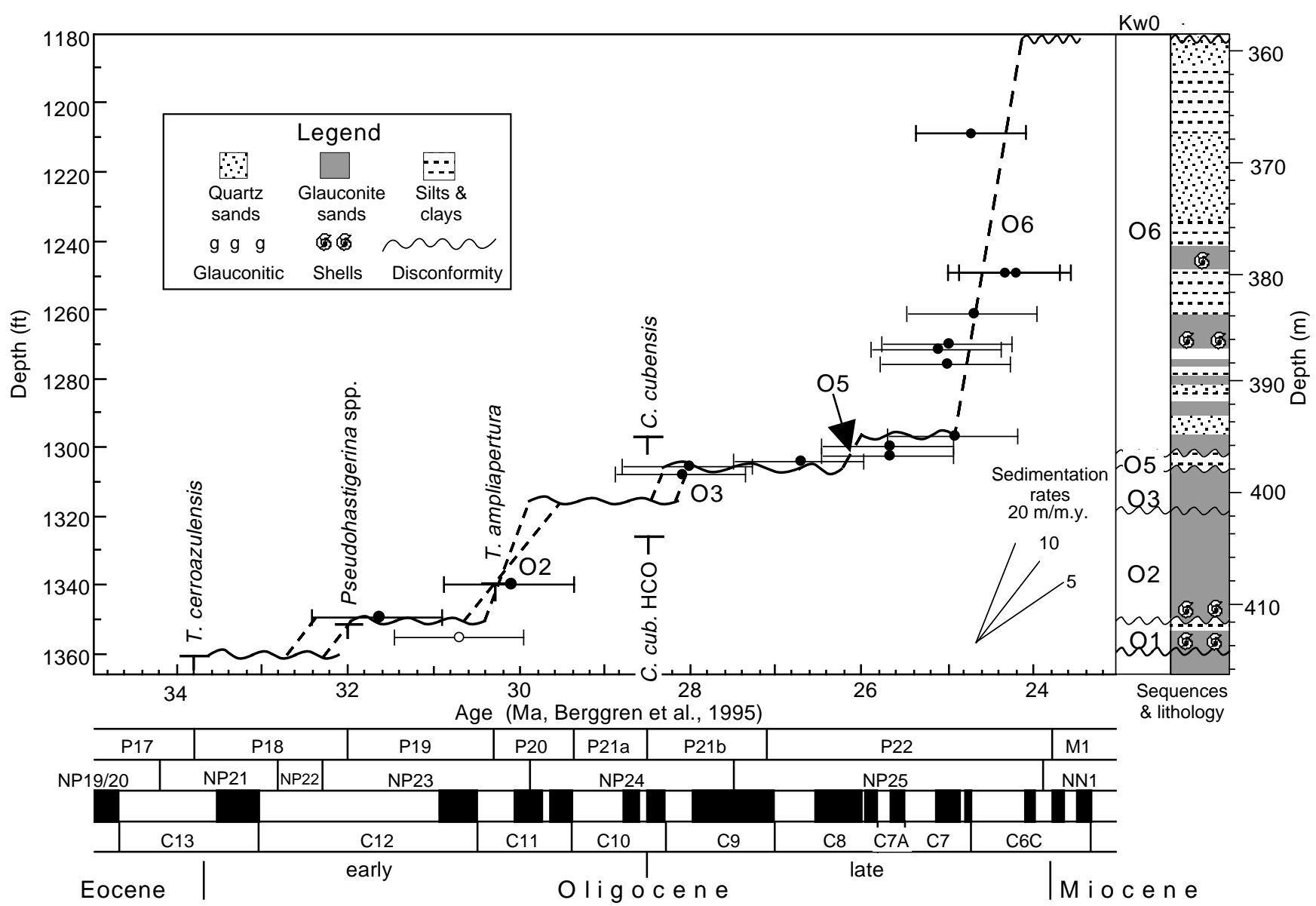

Figure 7. Cape May age vs. depth. Sr-isotopic ages are shown as solid points with \pm 0.8 -m.y error bars. The HO of $T$. ampliapertura does not include one isolated specimen at $1275.9(388.9 \mathrm{~m})$ that is interpreted as reworked. Open Sr-isotopic value is considered an outlier due to stratigraphic inversion. $\mathrm{HCO}=$ highest consistent occurrence.

tent occurrence (HCO) agrees with other data (Figs. 7, 8). Tentative correlations of magnetochron boundaries at Island Beach (Van Fossen, Chapter 22, this volume) are also shown (Fig. 9).

\section{Sequence 01}

Sequence $\mathrm{O} 1$, the oldest sequence in the New Jersey Oligocene (composite age 32.8-32.2 Ma; Fig. 2), is a thin sequence identified only at Cape May (Fig. 7; 1360-1350.8 ft [414.5-411.7 m]) and Island Beach (Fig. 9; 697-678 ft [212.4-206.7 m]). The lower bounding surfaces at both sites are identified by spikes in the gamma-ray $\log$ (Figs. 4, 6) and a change in lithology from clays below to shells and glauconite sand above.

The $\mathrm{O} 1$ basal unconformity at Island Beach (Fig. 9) represents a hiatus of $\sim 0.9$ m.y., indicated by the HO of Hantkenina spp. (33.7 $\mathrm{Ma})$ at $698 \mathrm{ft}$ (212.8 m; Liu et al., Chapter 10, this volume) and the base of Zone NP22 (32.8 Ma) at $697 \mathrm{ft}$ (212.4 m; Miller, et al., 1994; Figs. 6, 9). The lower Oligocene equivalent of Biochron NP21 (i.e., the portion of the zone younger than the $\mathrm{HO}$ of Hantkenina spp.; 34.2-32.8 Ma) is not represented at Island Beach. The O1 sequence at Island Beach is assigned to Zone NP22 (Miller, et al., 1994) and is equivalent to Biochron $\mathrm{P} 18$ partim. The maximum duration of the sequence at Island Beach is $32.8-32.3 \mathrm{Ma}$ (i.e., Biochron NP22; minimum sedimentation rate $11.4 \mathrm{~m} / \mathrm{m} . \mathrm{y}$.).

The basal unconformity at Cape May represents a hiatus of as much as 1.8 m.y. between the HO of Turborotalia cerroazulensis cerroazulensis $(33.8 \mathrm{Ma})$ at $1360 \mathrm{ft}(414.5 \mathrm{~m})$ and the $\mathrm{HO}$ of Pseudohastigerina spp. (32.0 Ma; Liu et al., Chapter 10, this vol- ume). A Sr-isotopic age estimate of 31.6 Ma was obtained from the basal reworked zone of the overlying sequence $(1350.0 \mathrm{ft}$ [411.6 m]; Fig. 7); if we use 32.4 Ma as the minimum age of the top of Sequence $\mathrm{O} 1$ (Sr age of 31.6 plus 0.8 m.y. error; Fig. 7) and assume a sedimentation rate of $11.4 \mathrm{~m} / \mathrm{m}$.y. (as at Island Beach), the hiatus may be as short at $1.4 \mathrm{~m} . \mathrm{y}$. Although the sampling interval $(10 \mathrm{ft}[3.0 \mathrm{~m}])$ and age control are coarse in this sequence, a significant hiatus between $\mathrm{O} 1$ and the Eocene is required, or mean sedimentation rates would be less than $2 \mathrm{~m} / \mathrm{m}$.y. The Cape May O1 (Figs. 4, 7) sequence is assigned to Zone P18 (Liu et al., Chapter 10, this volume) and is equivalent in age to Biochron NP22. Assuming a sedimentation rate of $11 \mathrm{~m} / \mathrm{m} . \mathrm{y}$. as at Island Beach (Fig. 7), O1 at Cape May is dated as from 32.0 (i.e., the $\mathrm{HO}$ of Pseudohastigerina spp.) to 32.2 or $32.3 \mathrm{Ma}$ (Fig. 2). However, it is possible that the $\mathrm{HO}$ of Pseudohastigerina spp. is truncated; in this case, the sequence could be as old as 32.4-32.7 Ma. We show the age of this sequence at Cape May as uncertain (32.7-32.0 Ma; Fig. 2).

The $\mathrm{O} 1$ sequence may correlate to the lowermost Oligocene Mays Landing unit (Owens et al., 1988) observed at the ACGS\#4 borehole. However, nannofossil data (Poore and Bybell, 1988) indicate that the Mays Landing unit is slightly older (Zone NP21) than the O1 sequence at Cape May and Island Beach and may, in fact, represent another sequence.

\section{Sequence $\mathrm{O2}$}

Sequence O2 (composite age 30.8-29.9 Ma; Fig. 2) is represented in all three boreholes (Fig. 2). At Island Beach (Fig. 6), it is thicker 


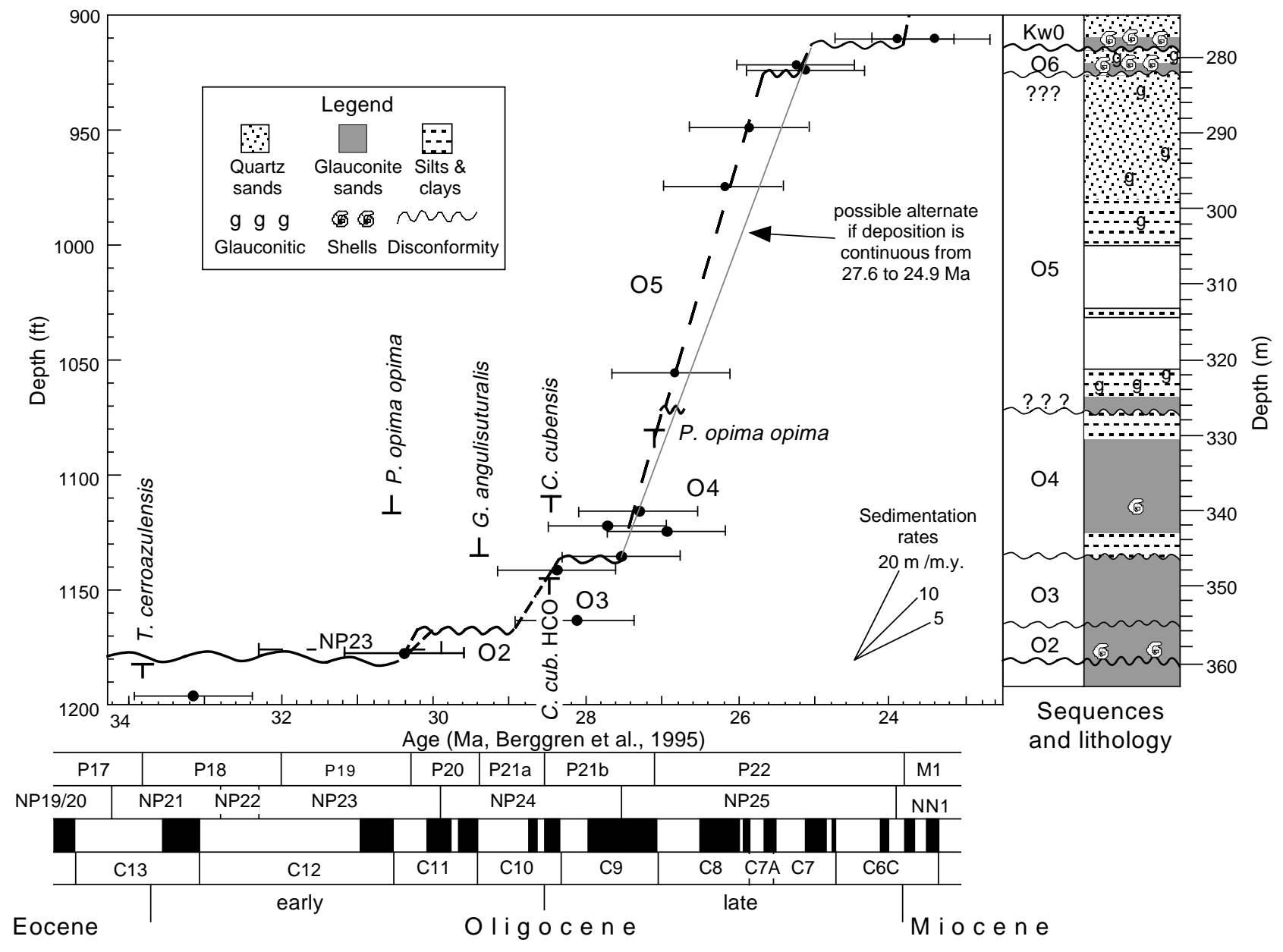

Figure 8. Atlantic City age vs. depth.

(95 ft [29.0 m]) than at Atlantic City (Fig. 5, $15 \mathrm{ft}$ [4.6 m]) or Cape May (Fig. 4, $36 \mathrm{ft}[11.0 \mathrm{~m}]$ ). The basal O2 sequence boundary is recognized at all three boreholes by (1) gamma-ray log increases at the sequence boundaries (Figs. 4-6), (2) abrupt changes in the lithology across the sequence boundaries (from clays below to clayey glauconite sand above; Figs. 4-6), and (3) abrupt shifts in the benthic foraminiferal biofacies at Atlantic City and Cape May (Figs. 4, 5).

The sequence boundary at the base of $\mathrm{O} 2$ represents a significant hiatus. At Cape May (Figs. 4, 7), we estimate a hiatus of 1.3-1.6 m.y. between Sequences O2 and O1 based on (1) the HO of Pseudohastigerina spp. (32.0 Ma) below the sequence boundary (1351 ft, 414.6 $\mathrm{m}$; Liu et al., Chapter 10, this volume), (2) the HO of T. ampliapertura above (30.3 Ma; $1340 \mathrm{ft}$ [408.5 m]), (3) two Sr-isotopic age estimates of $30.1 \mathrm{Ma}$ above $(1340 \mathrm{ft}$ [408.4 m]; note that a third estimate of $28.5 \mathrm{Ma}$ at this level is considered an outlier), and (4) the assumption that sedimentation rates were $10-20 \mathrm{~m} / \mathrm{m}$.y. (Fig. 7). Assuming the higher rate, O1 at Cape May (1350.8-1314.8 ft [411.7-400.8 m]) is dated from $\sim 30.4$ to $29.9 \mathrm{Ma}$; assuming the lower rate, the sequence is $\sim 30.7-29.6 \mathrm{Ma}$ (Fig. 2).

At Atlantic City (Fig. 8), a long hiatus (3.8 m.y.) separates Sequence $\mathrm{O} 2$ from the Eocene. The hiatus is indicated by the $\mathrm{HO}$ of Discoaster saipanensis (34.2 Ma; Miller, et al., 1994) and Turborotalia cerroazulensis cerroazulensis (33.8 Ma; Liu et al., Chapter 10, this volume ) at $1181 \mathrm{ft}(360.0 \mathrm{~m})$, and a Sr-isotopic age estimate of 30.4 $\mathrm{Ma}$ at $1178 \mathrm{ft}$ (359.1 m; Fig. 8). The $\mathrm{O} 2$ sequence at Atlantic City (1181-1166 ft [360-355.4 m]) is dated only by this Sr-isotopic age estimate and a limited nannofossil assemblage, placing it within Zone NP 23 (32.2-29.9 Ma; Miller, et al., 1994). Assuming sedimentation rates of 10-20 m.y. (Fig. 8), we estimate the age of this sequence as 30.4 to 30.0 or $30.2 \mathrm{Ma}$ (Fig. 2).

At Island Beach (Fig. 9), we estimate that a hiatus of 0.8-1.5 m.y. (Fig. 9) separates Sequence O2 from O1, based on the top of NP22 (32.3 Ma) at $680 \mathrm{ft}$ (207.3 m; Miller, et al., 1994) and a Sr-isotopic age estimate of $31.5 \mathrm{Ma}$ at $677 \mathrm{ft}(206.3 \mathrm{~m})$. The $\mathrm{O} 2$ sequence at Island Beach (Fig. 9, 697-602 ft [212.4-183.4 m]) is equivalent to Biochron P19 partim and perhaps earliest P20, based on the $\mathrm{HO}$ of T. ampliapertura at $618 \mathrm{ft}$ (188.4 m; Fig. 9) and three Sr-isotopic age estimates of $31.5 \mathrm{Ma}, 31.1 \mathrm{Ma}$, and 31.1 Ma, at 677, 668, and $663 \mathrm{ft}(206.3$, 203.6, and $202.1 \mathrm{~m}$ ), respectively. A magnetically reversed interval occurring between 658.5 and $612.15 \mathrm{ft}(200.7$ and $186.6 \mathrm{~m})$ is tentatively identified as Chronozone C12r (33.1-30.9 Ma; Van Fossen, Chapter 22, this volume). However, it is possible to interpret this reversed polarity interval as Chron C11r. Best-fit lines among the magnetostratigraphic, biostratigraphic, and $\mathrm{Sr}$-isotopic stratigraphic data provide age estimates of either 30.8-30.1 Ma (assuming Chron C11r) or 31.4-30.9 Ma (assuming Chron C12r) for O2 at Island Beach (Fig. 2). We prefer the interpretation of Chron $\mathrm{C} 11 \mathrm{r}$, because it results in synchronous age estimates for $\mathrm{O} 2$ at all three sites (Fig. 2). Both interpretations require high sedimentation rates $(41-58 \mathrm{~m} / \mathrm{m} . \mathrm{y}$.)

\section{Sequence $\mathrm{O3}$}

Oligocene Sequence O3 is represented at Atlantic City (1166$1138 \mathrm{ft}$ [355.4-346.9 m]) and Cape May (1314.8-1304.8 ft [400.8$397.7 \mathrm{~m}]$ ) and has a preferred age estimate of 29.0-28.3 Ma (Fig. 2; straddling the early/late Oligocene boundary), although it is possible 


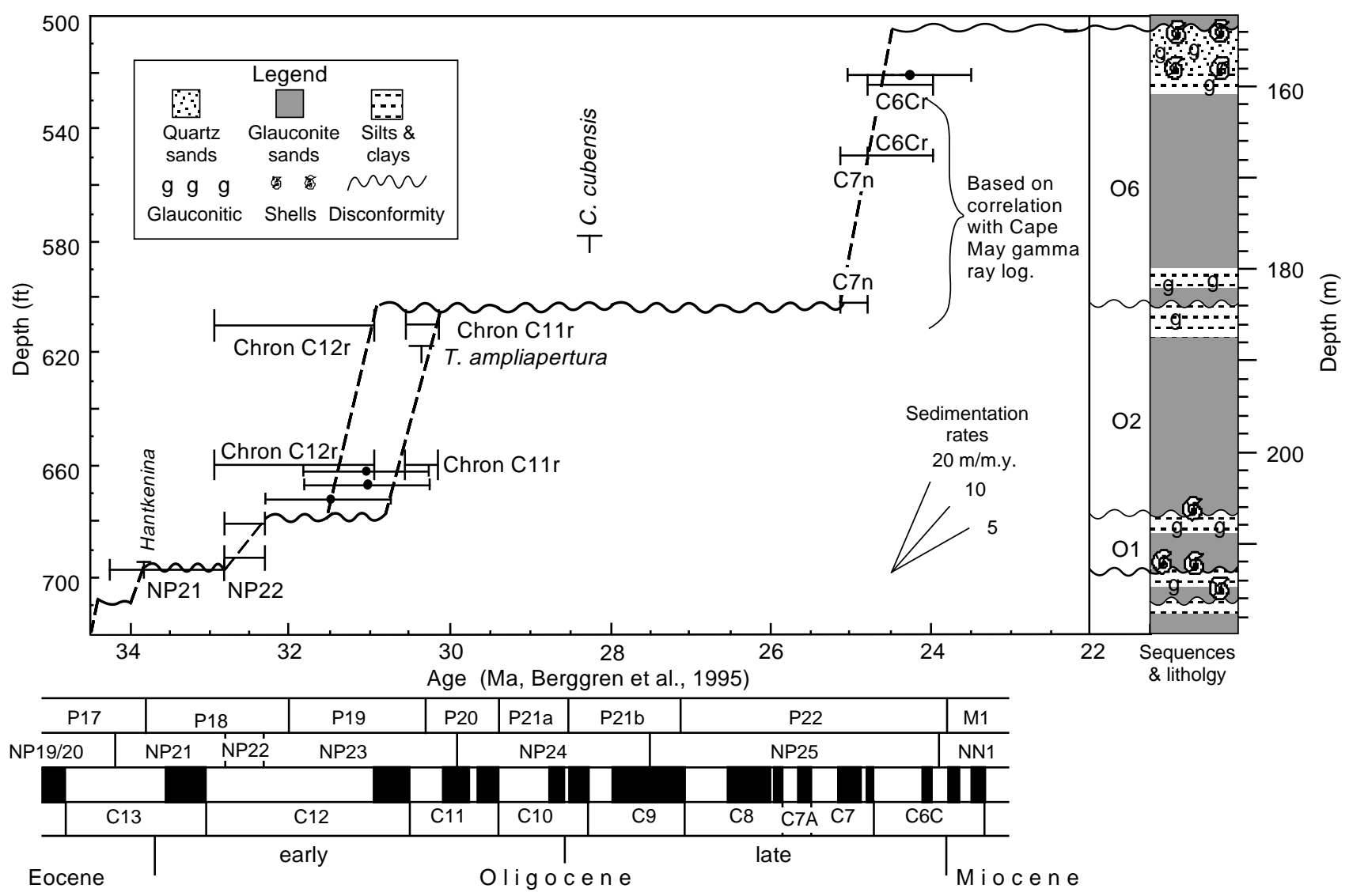

Figure 9. Island Beach age vs. depth.

that it is as young as $28.0 \mathrm{Ma}$. An unconformity marking the base of the sequence at Atlantic City is indicated by a lithofacies change from a glauconitic silty clay below to a shelly glauconite sand above, and a low-amplitude gamma-ray increase (Fig. 5). Sr-isotopic age estimates clearly indicate a greater than 1-m.y. hiatus at this disconformity (Fig. 8). As noted above, the $\mathrm{HO}$ of Chiloguembelina cubensis is attributed to reworking, as it is at Cape May. However, the HCO (Fig. 8) of this taxon fits very well with the $\mathrm{Sr}$-isotopic age estimates (Fig. 8). Assuming a sedimentation rate of $20 \mathrm{~m} / \mathrm{m}$.y. (Fig. 8), we estimate that this sequence was deposited from 29.0 to 28.3 Ma (Fig. 2).

At Cape May, an unconformity at the base of $\mathrm{O} 3$ is indicated at $1314.8 \mathrm{ft}(400.8 \mathrm{~m})$ by a sharp change in lithology from sandy clays below to clayey glauconite sand above and is associated with an increase in water depth. Sr-isotopic age estimates clearly indicate a hiatus of at least 1.3 m.y. at this unconformity (Fig. 7). Chiloguembelina cubensis identified in the overlying sequence at Cape May is interpreted as reworked (i.e., it is absent in $\mathrm{O} 3$ and its $\mathrm{HCO}$ is in $\mathrm{O} 2$ ). The age of this sequence is poorly dated at Cape May. Assuming a sedimentation rate of $20 \mathrm{~m} / \mathrm{m}$.y. (Fig. 8) through the Sr-isotopic ages, we estimate that this sequence was deposited from 28.1 to $28.0 \mathrm{Ma}$ (Fig. 2). Assuming this rate fixed at the $\mathrm{HCO}$ of $C$. cubensis, the sequence is 28.5-28.4 Ma (Fig. 7); this is the preferred age because it results in the same age for $\mathrm{O} 3$ at both sites (Fig. 2).

\section{Sequence 04}

Sequence O4 is represented only at Atlantic City $(1138-1072 \mathrm{ft}$ [346.9-326.7 m] Fig. 5) and is correlated to Biochron P21b. The basal disconformity (Fig. 5) is indicated by (1) a sharp gamma-ray increase, (2) an abrupt change in lithology from generally glauconite sand below to clays above, and (3) a shift across the boundary in the dominant benthic foraminiferal species (from Biofacies $\mathrm{G}$ below to Biofacies C above). Integrated biostratigraphy and $\mathrm{Sr}$-isotopic stratigraphy indicate a $0.8-\mathrm{m}$.y. hiatus between Sequences O4 and O3 (Fig. 8). The $\mathrm{O} 4$ sequence was dated by the $\mathrm{HO}$ of $P$. opima opima $(27.1 \mathrm{Ma} ; 1078 \mathrm{ft}[328.6 \mathrm{~m}])$ and four $\mathrm{Sr}$-isotopic age estimates of 27.3, 27.7, 26.9, and 27.5 Ma at 1117, 1123, 1124, and $1135 \mathrm{ft}(340.5$, $342.3,342.6$, and $345.9 \mathrm{~m}$ ), respectively. A best fit through the Srisotopic and biostratigraphic data indicates an age of 27.5-27.0 Ma (Figs. 2, 8).

\section{Sequence 05}

Sequence O5 is observed at Atlantic City (1072-923 ft [326.7$281.3 \mathrm{~m}]$ ) and Cape May (1304.8-1300 ft [397.7-396.2 m]) and has a composite age of 27.0-25.6 Ma (Fig. 2), correlating it with Biochron P22. At Atlantic City (Fig. 5), an unconformity marking the base of $\mathrm{O} 5$ is indicated at $1072 \mathrm{ft}(326.7 \mathrm{~m})$ by an abrupt shift in lithology. The sequence is dated by four $\mathrm{Sr}$-isotopic age estimates (one duplicate) ranging from 26.8 to $25.9 \mathrm{Ma}$ (Figs. 5, 8). There is no discernible hiatus at this site (i.e., it is less than 0.5 m.y.)

The basal unconformity at Cape May (1304.8 ft [397.8 m]) separating Sequence $\mathrm{O} 5$ from the underlying O3 (Fig. 4) is indicated by a shift in the benthic foraminiferal biofacies from $\mathrm{G}$ below to $\mathrm{C}$ above and a shift in the lithology across the unconformity. At Cape May, we estimate that a 1.8-m.y. hiatus is associated with the sequence boundary (Fig. 7). The sequence is dated at Cape May by Sr-isotopic age estimates of $25.7 \mathrm{Ma}$ at 1300 and $1302 \mathrm{ft}(396.2$ and $396.8 \mathrm{~m})$ and 26.7 Ma at $1303.8 \mathrm{ft}$ (397.5 m; Figs. 4, 7). Assuming sedimentation rates of $10-20 \mathrm{~m} / \mathrm{m}$.y. through a best fit of the three Sr-isotopic ages (Fig. 8), we estimate that this sequence at Cape May was deposited between 26.2 and 26.1 or $26.0 \mathrm{Ma}$ (Fig. 2). 


\section{Sequence 06}

Sequence O6, the youngest sequence detected in the New Jersey Oligocene, is present in all three boreholes (Figs. 4-6) and has a composite age estimate of 25.1-24.2 Ma, correlating it with late Biochron $\mathrm{P} 22$. The duration of the hiatus associated with the basal unconformity is not well constrained because the hiatuses at Atlantic City (0.6 m.y.) and Cape May (1.1 m.y.) are based on Sr-isotopic ages alone and thus are not or are barely within the resolution of this method $( \pm 0.8$ m.y.). Although a significant change in baselevel is indicated at all three sites by lithologic changes and a gamma-ray log increase, a shift in the benthic foraminiferal biofacies occurs only at Atlantic City. Thus, it is possible that Sequences O5 and O6 at Cape May and Atlantic City may actually represent one sequence. In that case, the lithologic and benthic foraminiferal biofacies changes observed within this sequence could reflect two parasequences within one O5-O6 sequence. The age of O6 is constrained at Island Beach to 25.1-24.5 Ma by integration of one $\mathrm{Sr}$-isotopic age and a polarity sequence that is correlated to Chrons C6Cr-C7n (Fig. 9). At Cape May, Sr-isotopes constrain the age of Sequence O6 to 24.9-24.2 Ma, agreeing well with Island Beach. The age at Atlantic City is not well constrained.

\section{Benthic Foraminiferal Biofacies: Atlantic City and Cape May}

Changes in benthic foraminiferal biofacies represent changes in habitat. Such changes in habitat result from environmental changes, including those that covary with water depth (Walton, 1964). Integration of benthic foraminiferal biofacies with lithologic data can be used to constrain intrasequence facies changes, paleoenvironmental conditions, and the relative magnitude of water-depth changes. Eight benthic foraminiferal biofacies are recognized in the Leg 150X Oligocene sections, named here Biofacies A through $\mathrm{H}$, with Biofacies A representing species that lived in the shallowest waters and $\mathrm{H}$ the deepest (Figs. 10-12).

\section{Biofacies A}

Biofacies A is interpreted to have inhabited inner neritic paleodepths $(<30 \mathrm{~m})$ based on lithologic and faunal indicators. It is represented by Factor 6 (9.5\% of the total variance explained), which is dominant only in Cape May samples at $1200 \mathrm{ft}(365.8 \mathrm{~m})$ and between 1212 and $1233 \mathrm{ft}$ (369.4 and $375.8 \mathrm{~m})$. Dominant species are Nonionellina pizarrensis (36\%, average percentage), Bulimina gracilis (17\%), Hanzawaia spp. (12\%), and Cibicides spp. (5\%; see Pekar, 1995 for percentage data; data are available on request from the authors). Buliminella curta is an important taxon as shown by factor scores, although it is always subordinate to $B$. gracilis. We interpret $N$. pizarrensis as an inner neritic taxon based on (1) its association with medium- to coarse-grained quartz sand, indicative of inner neritic environments; (2) high species dominance within this biofacies; (3) low planktonic percentages within this biofacies; and (4) a similar taxon, Nonionella atlanticus, which has a modern depth range of 20$50 \mathrm{~m}$, with the highest abundance at $20 \mathrm{~m}$ (Schnitker, 1971). The genus Hanzawaia has been identified in inner to middle neritic environments in the Gulf of Mexico (Poag, 1981) and off the North Carolina coast (Sen Gupta and Kilborne, 1976). Biofacies A has an average of five benthic foraminifers per gram; raw diversity (number of species per sample) averages 14 species per sample (both are the lowest observed in this study). This is the shallowest water biofacies encountered in the Leg 150X Oligocene sections.

\section{Biofacies B}

Biofacies B is observed only at Atlantic City (989-980 ft [301.4$298.7 \mathrm{~m}]$ ) and is the shallowest water biofacies (inner neritic, $<30 \mathrm{~m}$, Fig. 10) identified there. It is represented by negative loadings on Factor 9 (Fig. 11;3.8\% of variation explained). The dominant species are Nonionella auris (27\%, average percentage), Spiroplectammina gracilis (16\%), and Quinqueloculina seminulum (10\%; Fig. 11). Nonionella spp. occur in inner neritic environments in the Gulf of Mexico (Poag, 1981). This biofacies was observed primarily in samples consisting of quartz sand (within a coarsening-upward succession), indicative of inner to inner middle neritic environments (Pekar, 1995). The number of benthic foraminifers per gram (six) is low (Fig. 10); raw diversity is also low (average number of species per sample is 17). This indicates a high-stress environment, also suggesting a shallow-water environment.

\section{Biofacies $C$}

Biofacies C inhabited slightly deeper water than Biofacies B (inner middle neritic, $\sim 30-50 \mathrm{~m}$ ). Benthic foraminiferal Biofacies $\mathrm{C}$ is represented by Factor 2 (13.7\% of the total variance explained). Dominant species include Bulimina gracilis (50\% average percentage), Nonionellina pizarrensis (9\%), and Buliminella curta $(5 \%$, Fig. 12). Factor 2 is dominant for Cape May samples at $1275.9 \mathrm{ft}(388.6$ $\mathrm{m}), 1247-1240 \mathrm{ft}(380.0-378.0 \mathrm{~m})$, and $1209 \mathrm{ft}(368.5 \mathrm{~m})$ and for an Atlantic City sample at $1124 \mathrm{ft}(342.6 \mathrm{~m})$. B. gracilis occurs in modern shelf environments in the Gulf of Mexico (Poag, 1981). N. pizarrensis is estimated to have a paleodepth range of $20-0 \mathrm{~m}$. B. curta has a modern depth range from inner to middle neritic (Bandy, 1964). In two shallowing-upward successions (1249-1210 ft [380.7-368.8 m] and $1210-1181 \mathrm{ft}$ [368.8-360.0 m]), Biofacies $\mathrm{C}$ is overlain by inner neritic Biofacies A. This indicates a slightly deeper water-depth environment for Biofacies $\mathrm{C}$ than for Biofacies A. Raw diversity is 17 species per sample in Biofacies $\mathrm{C}$, and the number of benthic foraminifers per gram is 30 (Fig. 10); both are relatively low and are consistent with a shallow-water environment. This biofacies is observed within a lithology consisting of glauconitic clayey to silty finegrained quartz sand; it is interpreted as inner to inner middle neritic.

\section{Biofacies $D$}

Biofacies D is interpreted as a middle neritic biofacies (30-80 m). It is represented by Factor 5 (7.7\% of the total variance explained). It is found at Cape May between 1271 and $1253 \mathrm{ft}$ (387.4 and $381.9 \mathrm{~m}$ ) and at $1347 \mathrm{ft}(410.6 \mathrm{~m})$. Dominant species include Epistominella pontoni (24\%, average percentage), B. curta $(21 \%)$, and B. paula ( $21 \%)$. Epistominella spp. have been observed as a dominant species near the Mississippi delta (high sedimentation rates) in outer middle neritic (to abyssal) environments (Poag, 1981). B. curta occurs in inner to middle neritic environments along the west coast of Central America (Bandy, 1964) and in the Gulf of Mexico (Poag, 1981). B. paula is morphologically similar to the modern $B$. lowmani, which dominates along the Texas coast in outer shelf to upper bathyal depths (Poag, 1981). This biofacies averages 29 specimens per gram of sample; raw diversity is 18 species per sample (Fig. 10). Biofacies $\mathrm{D}$ is observed in the lower part of a well-developed shallowingupward succession at Cape May (1271-1209 ft [387.4-368.5 m]). It occurs in the lower clayey glauconite sands and clays and is overlain by glauconitic silts and fine-grained quartz sands (Biofacies $\mathrm{C}$ ) to medium- to coarse-grained quartz sands (Biofacies A), providing an indication of the relative bathymetric position of these biofacies.

\section{Biofacies $\boldsymbol{E}$}

Biofacies $\mathrm{E}$ is similar to the middle neritic Biofacies $\mathrm{D}$, but $\mathrm{E}$ inhabited slightly deeper water depths (middle to outer middle neritic environment, $50-100 \mathrm{~m})$. It is represented by Factor $7(6.7 \%$ of the total variance explained) and is found in Atlantic City samples between 1179 and $1156 \mathrm{ft}$ (359.4 and $352.3 \mathrm{~m})$. Dominant species are Epistominella pontoni (26\%, average percentage), Uvigerina spp. (U. nuttalli and U. glabrans dominate, 25\%), Bolivina paula (14\%), and Globocassidulina subglobosa $(7 \%)$. An outer middle neritic and deeper environment is interpreted based on the dominance of $B$. pau- 


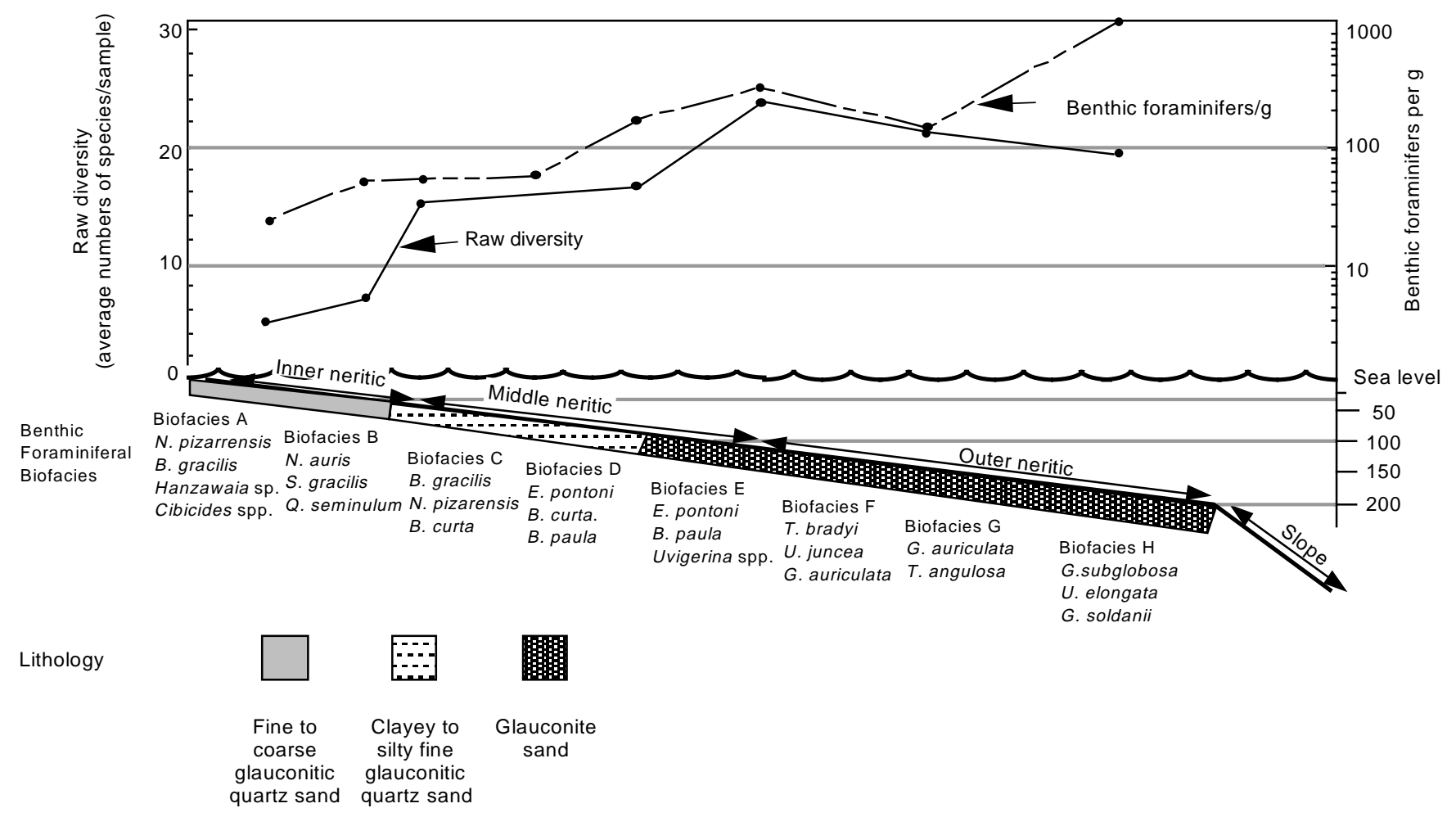

Figure 10. Paleobathymetry of benthic foraminifers for the Leg 150X Oligocene.

la, E. pontoni, and Uvigerina spp. This biofacies has an average of 43 benthic foraminifers per gram; raw diversity is 23 species per sample (Fig. 10). The lithology associated with Biofacies E often consists of clayey glauconite sand, consistent with a middle to outer neritic environment.

\section{Biofacies $\boldsymbol{F}$}

Biofacies $\mathrm{F}$ inhabited an outer middle to inner outer neritic biofacies $(75-125 \mathrm{~m})$ and is identified over an extensive section of the Oligocene at Atlantic City. It is represented by Factors 1 and 3. Factor 1 is dominant for Atlantic City samples between 1114 and $1102 \mathrm{ft}$ (339.5 and $335.9 \mathrm{~m}$ ) and at Cape May between 1303 and $1294 \mathrm{ft}$ (397.3 and $394.4 \mathrm{~m}$ ). Factor 3 is dominant at Atlantic City between $1091 \mathrm{ft}$ and the poorly recovered interval below $1000 \mathrm{ft}(332.5$ and $304.8 \mathrm{~m}$ ). The two factors explain $26.0 \%$ of the total variance. Dominant species for Factor 1 are Uvigerina juncea (36\%, average percentage) and Globobulimina auriculata (13\%). Trifarina bradyi is the dominant species for Factor $3(33 \%)$, followed by $U$. juncea $(12 \%)$ and B. paula $(6 \%)$.

The modern depth range of T. bradyi in the Gulf of Mexico is estimated by Phleger and Parker (1951) as outer middle neritic and deeper. G. auriculata has been observed in outer neritic environments along the northeast Atlantic margin (Kafescioglu, 1975). This biofacies occurs in a lithology of fine-grained clayey glauconite sand and occasionally with a low percentage of silts and very fine-grained quartz sand, indicative of middle to outer neritic environments (Pekar, 1995). Raw diversity is second highest of the biofacies, with an average of 27 species per sample (Fig. 10). Biofacies F contains the highest number of benthic foraminifers per gram (216).

\section{Biofacies $G$}

Biofacies $\mathrm{G}$ occupied the second deepest water depths (outer neritic environment, 100-150 m) in the Leg $150 \mathrm{X}$ Oligocene sections. It is represented by Factor 4 ( $8.1 \%$ of the total variance explained) and is found at Atlantic City between 1149 and $1135 \mathrm{ft}$ (350.2 and 345.9 $\mathrm{m}$ ) and at Cape May between 1307 and $1305 \mathrm{ft}$ (398.4 and $397.8 \mathrm{~m}$ ). Dominant species are G. auriculata (20\%, average percentage), Trifarina angulosa (18\%), and G. subglobosa (11\%).

$T$. angulosa is observed in modern outer neritic environments along the northeast Atlantic margin (Kafescioglu, 1975; Sen Gupta, 1971) and along the modern North Carolina shelf edge (60-140 m; Schnitker, 1971). Specimens of Globobulimina auriculata in Atlantic City and Cape May samples are often thin walled, suggesting a lowoxygen environment. This is based on the observation by Miller and Lohmann (1982) that modern, thin-walled G. auriculata specimens favor oxygen-minimum zones. Kafescioglu (1975) estimated an outer neritic environment for G. auriculata. G. subglobosa is found in outer neritic to abyssal depths in the Gulf of Mexico by Poag (1981) and on the Georgia shelf and deeper by Sen Gupta and Kilborne (1976). Tiptonina nodifera, a minor species in Biofacies G, was positively identified only in Atlantic City samples at $1145 \mathrm{ft}(349.0 \mathrm{~m})$. T. nodifera is among the deepest water benthic foraminifers observed in the New Jersey Oligocene, with an estimated paleodepth of upper bathyal (Lamb and Miller, 1984). In other samples within Biofacies $\mathrm{G}$, specimens of $T$. nodifera were poorly preserved, resulting in uncertain identification. B. jacksonensis, also a minor species, was observed only in the two deepest water biofacies ( $\mathrm{G}$ and $\mathrm{H})$ and is observed in outer neritic to upper bathyal environments (Van Morkhoven et al., 1986). Biofacies $\mathrm{G}$ has a relatively high number of benthic foraminifers per gram (148) and moderate raw diversity (average of 21 species per sample). Biofacies $\mathrm{G}$ is often observed in a lithology consisting of clayey glauconite sand, consistent with a deep-water interpretation for Biofacies G.

\section{Biofacies $\boldsymbol{H}$}

Benthic foraminiferal Biofacies $\mathrm{H}$ inhabited the deepest water (outer neritic, $\sim 100-200 \mathrm{~m})$ and is represented by Factor $8(5.5 \%$ of the total variance explained). Factor 8 is found at Cape May between 1354 and $1351 \mathrm{ft}$ (412.7 and $411.8 \mathrm{~m}$; Fig. 12). It is also found in two 


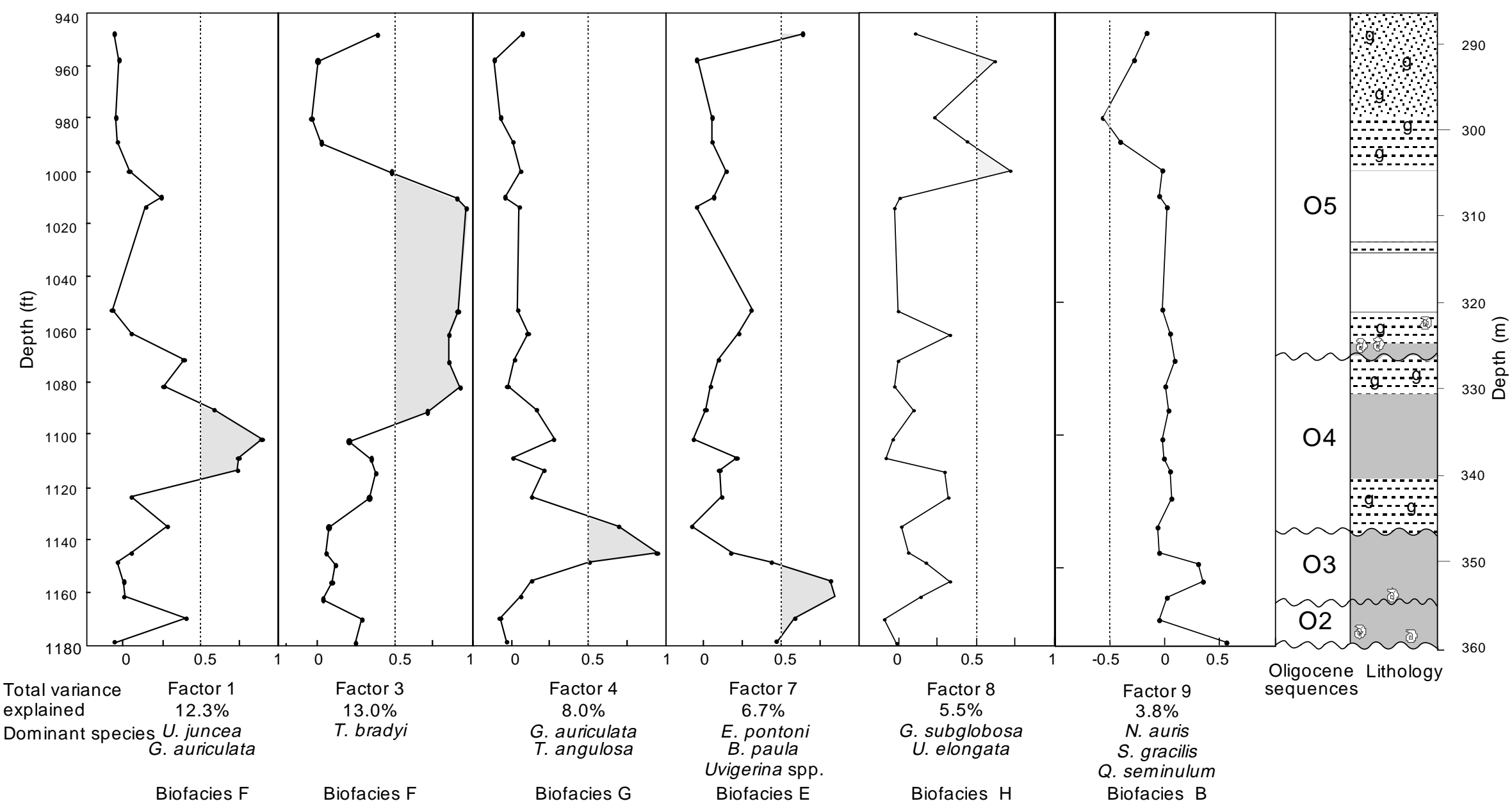

Figure 11. Factors and associated species, generalized stratigraphic column, and Oligocene sequences represented at Atlantic City. 


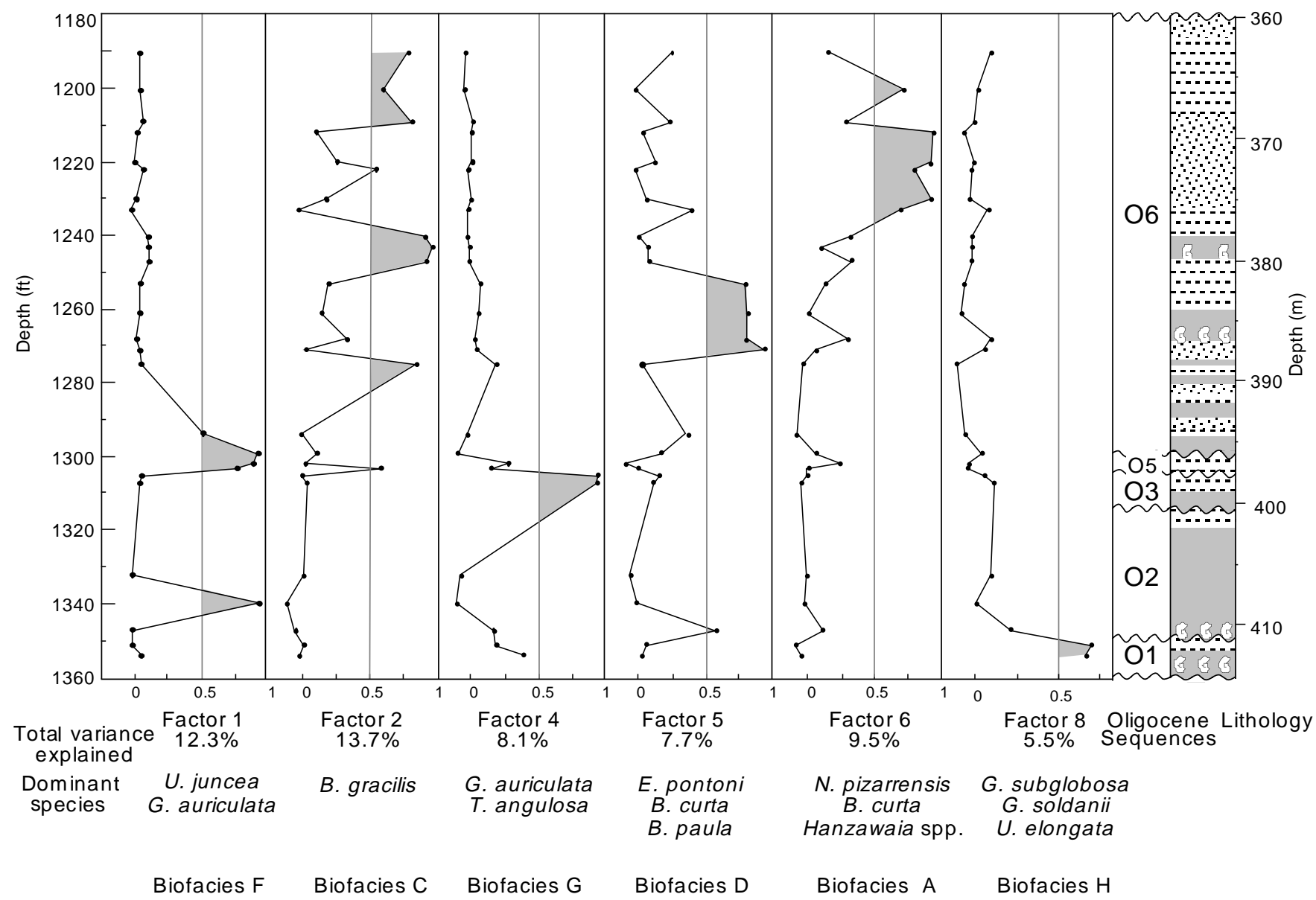

Figure 12. Factors and associated species, generalized stratigraphic column, and Oligocene sequences represented at Cape May.

samples at Atlantic City, 1000 and $958 \mathrm{ft}$ (304.9 and $292.1 \mathrm{~m})$, although preservation in the latter sample is poor and loading on this factor may be spurious. Globocassidulina subglobosa is the dominant species in Factor 8 (22\%, average percentage), followed by $U v i$ gerina elongata (10\%). Gyroidinoides soldanii also is an important taxon (Fig. 12). G. subglobosa occurs near the shelf break and in the upper bathyal zone and deeper in the Gulf of Mexico (Poag, 1981) and at the shelf break off the North Carolina coast (Sen Gupta and Kilborne, 1976). This species is used as an indicator of deeper water depths for paleobathymetry for the Oligocene samples. U. glabrans and Bulimina jacksonensis are minor species present when Factor 8 is dominant. U. glabrans is interpreted as upper bathyal (Boersma, 1984) and B. jacksonensis is interpreted as at outer neritic and upper bathyal (Van Morkhoven et al., 1986). Biofacies H contains the highest raw diversity of benthic foraminifers with an average of 31 species per sample, suggesting a deeper water, more stable environment. The average number of benthic foraminifers per gram is 88 . The lithology from 1354 to $1351 \mathrm{ft}(412.7-411.8 \mathrm{~m})$ at Cape May consists primarily of clayey glauconite sand and glauconitic clays, consistent with a middle to outer neritic environment.

\section{Paleoenvironments and System Tract Interpretation}

Paleoenvironments and system tracts are interpreted by integrating lithofacies, benthic foraminiferal biofacies, and gamma-ray log data (Figs. 4-6). At Cape May and Island Beach, lower and uppermost Oligocene sequences are well represented. At Atlantic City, mid-Oligocene sequences are also represented.

\section{Sequence 01}

The oldest New Jersey Oligocene sequence, O1, occurs at Cape May (Fig. 4) and Island Beach (Fig. 6) where it has similar lithologies. At Cape May, the basal surface is lost in a coring gap. However, the lowest recovered portion consists of thin shells $(1354.5-1352.5 \mathrm{ft}$ [412.9-412.2 m]) grading upsection to clayey glauconite sand (1352.5-1350.8 ft [412.2-411.7 m]). At Island Beach (Fig. 6), the base is recognized by a change from clays below to weathered shells above (697-696 ft [212.4-212.1 m]), which is in turn overlain by burrowed glauconitic quartz sand (696-678 ft [212.1-206.7 m]). Biofacies $\mathrm{H}$ dominates the sequence at Cape May (Fig. 12), representing the deepest water fauna observed in the Leg 150X Oligocene sections. The entire sequence at Cape May consists of glauconitic clayey silts that are assigned to the TST (Fig. 4); the HST is apparently truncated. At Island Beach, quartz sand increases at the top of the sequence, representing a thin, truncated HST (Fig. 6).

\section{Sequence $\mathrm{O2}$}

Sequence $\mathrm{O} 2$ is the thickest and most widespread lower Oligocene sequence and is represented at all three sites. At Cape May (Fig. 4), the TST glauconite sands and the lower HST silts compose the entire sequence $(1350.8-1314.8 \mathrm{ft}$ [411.7-400.8 m]). The base of the sequence (1350.8-1342.0 ft [411.7-409.0 m]) consists of a silty glauconitic fine-grained quartz sand that fines upward to clayey glauconite sand (1342-1328 ft [409.0-407.8 m]), indicating a deepeningupward section. A deepening-upward succession is also indicated by 
the benthic foraminiferal biofacies: Biofacies D (middle neritic) lies just above the base of the sequence and is overlain by Biofacies $\mathrm{F}$ (outer middle neritic to outer neritic). A MFS is indicated at $1340 \mathrm{ft}$ $(408.5 \mathrm{~m})$ based on (1) the highest concentration of benthic foraminifers (Fig. 4), (2) a high percentage of Uvigerina spp. (80\%+) evidenced by high loadings on Factor 1 (Fig. 12), and (3) the highest concentration of glauconite (>90\% of the sand fraction; Fig. 4). This places the TST between 1350.8 and $1340 \mathrm{ft}$ (411.7 and $408.5 \mathrm{~m}$ ). The HST (1340-1314.8 ft [408.5-400.8 m]) shallows upsection, as indicated by a drop in glauconite and an increase in clays in the lower part (1332 to $1314.8 \mathrm{ft}$ ) and an increase in fine-grained quartz sand in the upper part $(\sim 1320 \mathrm{ft}$ and $1314.8 \mathrm{ft}$ [402.3 and $400.8 \mathrm{~m}])$. A dissolution zone (1327-1314.8 ft [404.5-400.8 m]) limits the environmental interpretation of the upper part of the sequence.

The O2 sequence at Atlantic City (Fig. 5; 1181.2-1166 ft [360.0$355.4 \mathrm{~m}]$ ) consists of a clayey glauconite sand, associated with benthic foraminiferal Biofacies E (middle-outer neritic). We assign the entire sequence to the TST; the HST appears to be truncated.

The O2 sequence at Island Beach (Fig. 6; 678-602 ft [206.7$183.5 \mathrm{~m}]$ ) is the thickest lower Oligocene sequence observed in New Jersey (76 ft [23.2 m]). It was deposited in a middle to outer neritic environment. The TST (678-622 ft [206.7-189.6 m]) consists of clayey fine- to medium-grained glauconite sands $(20 \%-40 \%)$. Above a possible MFS at $622 \mathrm{ft}(189.6 \mathrm{~m})$, glauconite sand decreases in size and slightly in abundance, whereas clay increases upsection to $602 \mathrm{ft}(183.5 \mathrm{~m})$. Dissolution of benthic foraminifers limits the paleoenvironmental interpretation. The decrease in glauconite sand and the increase in clays and silts above $622 \mathrm{ft}(189.6 \mathrm{~m})$ is interpreted as the lower HST. The upper part of the HST (quartz sand facies) appears to be truncated.

\section{Sequence $\mathrm{O3}$}

Sequence O3 is represented at Cape May $(1314.8-1304.8 \mathrm{ft}$ [400.8-397.7 m]) and Atlantic City (1166-1138 ft [355.4-340.8 m]). At Atlantic City (Fig. 5), water depths rapidly increase in the TST (1166-1145 ft [355.4-349.0 m]) from inner to outer neritic, as indicated by glauconite sand increasing to over $50 \%$ as quartz sand decreases from $15 \%$ to $<5 \%$, and a shift in the benthic foraminiferal biofacies from Biofacies E below to Biofacies G. A shallowing-upward lower HST (1145-1138 ft [349.0-340.8 m]) is indicated by a decrease in glauconite sand $(57 \%-23 \%)$ and an increase in clay $(\sim 30 \%$ to $>70 \%$; Fig. 5). Upper HST sands are absent, probably caused by truncation.

The O3 sequence at Cape May (Fig. 4) shows a rapid water-depth increase across the basal unconformity, as indicated by clays below the sequence boundary and clayey glauconite sand above. The TST is represented by glauconite sand (1314.8-1308.8 ft [400.8-398.9 $\mathrm{m}])$. An increase in silts and fine-grained quartz sands from 1308.8 to $1304.8 \mathrm{ft}(398.9-397.7 \mathrm{~m}$ ) is interpreted as the lower HST (Fig. 4). A dissolution zone between 1314.8 and $1310 \mathrm{ft}$ (400.8 and $399.3 \mathrm{~m}$ ) limits the environmental interpretation; however, benthic foraminiferal biofacies indicate an outer neritic environment from 1307.8 to $1305.8 \mathrm{ft}$ (398.6-398.5 m, Biofacies G).

\section{Sequence 04}

The $\mathrm{O} 4$ sequence is represented only at Atlantic City (Fig. 5; 1138-1072 ft [346.9-326.7 m]). An increase from inner middle to outermost middle neritic paleodepth occurs in the TST (1138-1095 ft [346.9-333.8 m]) based on:

1. a decrease in fine-grained quartz sand (from $27 \%$ to $8 \%$ between 1124 and $1109 \mathrm{ft}$ [342.6 and $338.0 \mathrm{~m}]$ ),

2. an increase in glauconite sand from $3 \%$ at $1135 \mathrm{ft}(345.9 \mathrm{~m})$ to over $30 \%$ between 1109 and $1099 \mathrm{ft}(342.6$ and $335.0 \mathrm{~m})$, and
3. a shift in the biofacies from $\mathrm{C}$ at $1124 \mathrm{ft}$ ( $342.6 \mathrm{~m}$, inner middle neritic) to $\mathrm{F}$ (outermost neritic).

A MFS occurs at $\sim 1115 \mathrm{ft}(\sim 339.9 \mathrm{~m})$ based on (1) the maximum abundance of benthic foraminifers at $1024 \mathrm{ft}(342.7 \mathrm{~m})$, (2) the maximum glauconite sand percentage at $\sim 110 \mathrm{ft}(338.4 \mathrm{~m})$, and (3) a shelly interval at the latter level. The HST $(\sim 1095-1072 \mathrm{ft}[333.8-$ $326.7 \mathrm{~m}]$ ) can be divided into a lower clay (up to $80 \%$ clays) and an upper sandier unit $(15 \%$ at $1099 \mathrm{ft}[335.0 \mathrm{~m}]$, increasing to $50 \%$ at $1091 \mathrm{ft}[332.5 \mathrm{~m}])$.

\section{Sequence 05}

The $\mathrm{O} 5$ sequence is represented at Cape May and Atlantic City. The sequence at Cape May (Fig. 4; 1304.8-1300 ft [397.7-396.2 m]) is thin $(4.8 \mathrm{ft}[1.5 \mathrm{~m}])$ and appears to be truncated. A rapid waterdepth increase within this thin sequence is indicated by a change from Biofacies C at $1303.8 \mathrm{ft}(397.4 \mathrm{~m})$ to Biofacies F at $1302 \mathrm{ft}(396.8 \mathrm{~m})$. We interpret the entire sequence as TST; the HST apparently was truncated.

At Atlantic City (Fig. 5), Sequence O5 (1072-923 ft [326.7-281.3 $\mathrm{m}]$ ) is a thick transgressive/regressive sequence. The TST (1072 to $\sim 1060 \mathrm{ft}$ [326.7-323.1 m]) consists of a basal clayey shelly sand unit, overlain by a clayey glauconite sand. We place the MFS at $\sim 1060 \mathrm{ft}$ (323.1 $\mathrm{m}$ ) based on (1) lithofacies and benthic foraminiferal changes, which indicate a deepening from $1072 \mathrm{ft}(326.7 \mathrm{~m} ;$ T. bradyi and $B$. gracilis) to $1062 \mathrm{ft}$ ( $323.7 \mathrm{~m}$, T. bradyi and G. subglobosa); (2) the highest concentration of benthic foraminifers at $1062 \mathrm{ft}(323.7 \mathrm{~m})$; and (3) the highest abundances of glauconite $(20 \%-30 \%)$ between 1062 and $1055 \mathrm{ft}$ (323.7 and $321.6 \mathrm{~m}$; Fig. 5). Clays increase at 1055 $\mathrm{ft}(323.7 \mathrm{~m})$, indicating the lower HST. The only core recovered between 1053 and $1001 \mathrm{ft}$ (321.0 and $305.2 \mathrm{~m}$ ) was a silty clay with little sand $(<1 \%)$; the position of this and the lithologic change from the silty clays and glauconite sand of the Sewell Point Formation below to the quartz and glauconite sands of the Atlantic City Formation above (see Pekar et al., for designation and discussion of these units) is uncertain. Fine- to medium-grained quartz (over 50\%) is found at $1000 \mathrm{ft}(304.8 \mathrm{~m})$, indicating the lower HST and a shallowing from middle to inner neritic paleodepths (Fig. 5). Preservation of benthic foraminifers decreases dramatically upsection; above $959 \mathrm{ft}(292.3$ $\mathrm{m})$, benthic foraminiferal biofacies are indeterminate. However, from 1001 to $959 \mathrm{ft}$ (305.1-292.3 m), a shallow-water environment is indicated by Biofacies $\mathrm{B}$ and high quartz sand percentages $(50 \%-$ $70 \%)$.

\section{Sequence 06}

Sequence O6 is represented at all three boreholes. At Cape May (Fig. 4), it extends from 1300 to $1181 \mathrm{ft}$ (396.2-360.0 m; Fig. 4). The TST is placed near the base of the sequence $(1290 \mathrm{ft}[393.1 \mathrm{~m}])$ based on the high glauconite, and the HST probably encompasses the rest of the sequence. The lower HST (1290-1261 ft [393.2-384.4 m]) consists of silty clay, and the upper HST comprises a classic coarsening-upward succession (1261-1209 ft [384.4-368.5 m]). Benthic foraminifers also indicate a shallowing from 1268 to $1210 \mathrm{ft}$ (386.5$368.8 \mathrm{~m}$ ) because of the presence of Biofacies D between 1271 and $1253 \mathrm{ft}$ (387.4 and $381.9 \mathrm{~m}$, middle neritic), Biofacies $\mathrm{C}$ between 1247 and $1240 \mathrm{ft}$ ( 380.7 and $378.0 \mathrm{~m}$, inner middle neritic), and Biofacies A between 1233 and $1212 \mathrm{ft}$ (375.8 and $369.4 \mathrm{~m}$, inner neritic). This is the only Oligocene sequence containing a relatively intact upper HST while also preserving the calcareous microfauna.

Embedded within this bathymetric signal are minor water-depth changes indicative of parasequences or fourth-order cycles (Fig. 4). From 1300 to $1275 \mathrm{ft}$ (398.1-387.1 m), three thin shallowing-upward successions (1300-1290.6 ft [397.8-393.2 m], 1290.6-1279.0 ft [393.2-389.8 m], and 1279.0-1274.9 ft [389.8-388.6 m]) consist of 
glauconite sand at the base, followed by glauconitic clays, glauconitic silts, and capped by glauconitic fine-grained sands. A relatively thick parasequence occurs between 1274.9 and $1210 \mathrm{ft}$ (388.6 and $368.8 \mathrm{~m}$ ). The basal surface is indicated by (1) a sharp change in lithology from clays below to shelly glauconitic medium- to coarsegrained quartzose sand above, (2) an abrupt shallowing from Biofacies $\mathrm{C}$ (inner middle neritic) below to Biofacies D (middle neritic) above, and (3) a shift in the dominant species assemblages. These four parasequences are recognized in the gamma-ray log by a sharp spike at their bases (Fig. 4). Another coarsening-upward succession occurs from 1210 to $1181 \mathrm{ft}(368.8-360.0 \mathrm{~m})$. A flooding surface is indicated at $1210 \mathrm{ft}(368.8 \mathrm{~m})$ by (1) a sharp gamma-ray peak, (2) a lithologic change from coarse-grained quartzose sands below to clayey fine to medium quartzose glauconitic sands above, and (3) a shift from Biofacies A (inner neritic) below to Biofacies C (inner middle neritic) above (Fig. 4).

The O6 sequence at Atlantic City is bounded by unconformable surfaces consisting of thick shell beds dominated by oysters at 923 and $914 \mathrm{ft}$ (281.3 and $278.6 \mathrm{~m}$; Fig. 5). These beds are similar to the shell beds observed in the Maryland Miocene sequences (Kidwell, 1989) and are interpreted as transgressive lags deposited in the shallowest part of the TST. The shell bed at Atlantic City grades into clayey sandy glauconite from 920 to $914 \mathrm{ft}(280.4-278.6 \mathrm{~m})$. This deepening succession is truncated by the next shell bed that is part of the overlying sequence (Kw0; see Miller et al., Chapter 14, this volume for discussion of this sequence). We suggest that the entire sequence is composed of the TST and that the HST is not preserved.

Sequence O6 at Island Beach extends from 602 to $505 \mathrm{ft}(183.5$ $153.9 \mathrm{~m}$; Fig. 6). The section from 602 to $558 \mathrm{ft}$ (183.5-170.1 m) consists of clayey fine to medium glauconite sand (TST; Fig. 6). Glauconite sand decreases and clays increase in the lower HST (558-540 $\mathrm{ft}$ [170.1-164.6 m]); medium quartz sands increase in the HST (540$505 \mathrm{ft}$ [164.6-153.9 m]; Fig. 6). Dissolution of the calcareous fossils in this sequence limits the environmental interpretation.

\section{DISCUSSION \\ Comparing New Jersey Sequences with a Glacioeustatic Proxy}

Glaciomarine sediments and $\delta^{18} \mathrm{O}$ changes (Miller et al., 1987) indicate that large ice sheets have grown and decayed since at least the earliest Oligocene. Miller et al. (1991) detected four benthic foraminiferal $\delta^{18} \mathrm{O}$ Oligocene to earliest Miocene increases (Fig. 2), Oi1, Oi2, Oi2b, and Mi1, with maximum $\delta^{18} \mathrm{O}$ values at 33.5 (Chron $\mathrm{C} 13 \mathrm{n}$ ), 30.0 (latest Chron C11r), 27.1 (Chron C9n), and 23.8 Ma (Chron C6Cn; Fig. 2) and inferred these to reflect, in part, glacioeustatic lowerings. These increases are associated with subtropical planktonic $\delta^{18} \mathrm{O}$ increases, suggesting at least some ice growth at these times (Miller et al., 1987, 1991). In addition, the Oi1, Oi2, and Mi1 increases (Fig. 2) appear to be associated with glaciomarine sediments in Antarctica, again suggesting a glacioeustatic component to the increases (Miller et al., 1991). Three other Oligocene $\delta^{18} \mathrm{O}$ increases were recognized by Pekar and Miller (1996) at 32.8 (Oi1a, early Chron C12r), 31.7 (Oi1b, mid Chron C12r), and 28.3 Ma (Oi2a, Chron C10n.1n).

We compare the Leg $150 \mathrm{X}$ Oligocene sequences to the $\delta^{18} \mathrm{O}$ record to determine if unconformities observed were controlled primarily by eustasy (Fig. 2). A comparison of the $\delta^{18} \mathrm{O}$ increases with the Oligocene sequence boundaries shows good correlation.

The unconformity at the base of Sequence O1 represents a hiatus (32.8-32.2 Ma) that encompasses both well-known Oi1 (33.5 Ma) and newly recognized Oila $(32.8 \mathrm{Ma}) \delta^{18} \mathrm{O}$ increases (Fig. 2). The Mays Landing unit at the ACGS\#4 borehole appears to have been deposited between the Oil and Oila $\delta^{18} \mathrm{O}$ increases (Fig. 2). Further study is needed to corroborate this.

A hiatus (32.2-30.8 Ma) associated with the $\mathrm{O} 2$ sequence boundary correlates well with Oilb $\delta^{18} \mathrm{O}$ increase (31.7 Ma; Fig. 2). A hia- tus (29.9-29.0 Ma) associated with the base of Sequence O3 appears to correlate with the $\mathrm{Oi} 2 \delta^{18} \mathrm{O}$ increase $(30.0 \mathrm{Ma})$; we attribute the slight (0.1 m.y.) discrepancy to age uncertainties of this sequence at Cape May. A hiatus (28.2-27.5 Ma) associated with the base of Sequence $\mathrm{O} 4$ correlates with $\mathrm{Oi} 2 \mathrm{a}(28.3 \mathrm{Ma})$. There is no discernible hiatus associated with the base of Sequence O5; however, this sequence boundary (27.0 Ma) correlates well (within $0.1 \mathrm{~m} . \mathrm{y}$.) with the Oi2b (27.1 Ma) $\delta^{18} \mathrm{O}$ increase (Fig. 2). The lower Miocene Kw0 basal sequence boundary (hiatus 24.2-23.6 Ma; see Miller et al., Chapter 14, this volume) correlates very well with the Mi1 (23.7 Ma) $\delta^{18} \mathrm{O}$ increase. The basal O6 sequence boundary (hiatus 25.6-25.1 Ma) may correlate with a minor $\delta^{18} \mathrm{O}$ increase at $25.0 \mathrm{Ma}$ (i.e., the $0.1-\mathrm{m}$.y. discrepancy is well within the age errors). Maximum $\delta^{18} \mathrm{O}$ values attained at this time $\left(1.6 \%\right.$ ) are significantly lower than the major $\delta^{18} \mathrm{O}$ events, and ice is not required at this time, although the $\delta^{18} \mathrm{O}$ increase $(0.6 \%$ ) is substantial enough that it probably reflects ice accumulation and a minor sea-level lowering (Pekar and Miller, 1996). We conclude that there is an excellent correspondence between the timing of $\delta^{18} \mathrm{O}$ increases and sequence boundaries. Because the $\delta^{18} \mathrm{O}$ increases must reflect glacioeustatic lowering, this links the formation of sequence boundaries to eustatic falls.

\section{Comparing New Jersey Oligocene Sequences with the Exxon Cycles}

The Exxon eustatic record (Haq et al., 1987) indicates that six third-order sea-level cycles occurred during the Oligocene to earliest Miocene (Haq et al., 1988; Fig. 2): TA4.4, TA4.5, TB1.1, TB1.2, TB1.3, and TB1.4. Differences in time scales complicate comparisons with Haq et al. (1987). We calibrated the Haq et al. (1987) record to the Berggren et al. (1995) time scale by interpolating between three points:

1. Miller et al. (1993) revised the correlation of the TB1.1 sequence boundary to latest Chron C11r ( 30.0 Ma on the Berggren et al. [1995] time scale).

2. The age of the Oligocene/Miocene boundary should be revised from 25.5 Ma (Haq et al., 1987) to 23.8 Ma (Berggren et al., 1995).

3. The Eocene/Oligocene boundary is $33.7 \mathrm{Ma}$.

The six Oligocene sequence boundaries recognized by Haq et al. (1987) show good correlation to the unconformities observed in the New Jersey Oligocene (Fig. 2). A hiatus dated from 28.2 to $27.5 \mathrm{Ma}$, occurs between the New Jersey Sequences O3 and O4. However, the Haq et al. (1987) eustatic record does not indicate a sea-level fall at this time. The $\delta^{18} \mathrm{O}$ record does detect a $\delta^{18} \mathrm{O}$ increase at $28.3 \mathrm{Ma}$ (Oi2a; Fig. 2). The correlation of this $\delta^{18} \mathrm{O}$ increase with the sequence boundaries observed in the New Jersey Oligocene sequences indicates that a eustatic fall may have occurred during this time. We also note a possible sequence boundary between $\mathrm{O} 1$ and the lowermost Oligocene Mays Landing unit, which has no corresponding equivalent in the Haq et al. (1987) record.

\section{Tectonics and Sequences}

Correlation of the three New Jersey boreholes shows that most of the lowermost and uppermost Oligocene sequences and their bounding unconformities correlate well from site to site (Fig. 2). It also shows that there were two major depositional centers during the early Oligocene (Biochrons P18-P20): one to the south (i.e., into the Salisbury embayment; see Owens et al., Chapter 2, this volume for location) and the other to the north near Island Beach. The thinnest lower Oligocene downdip sections occur near Atlantic City (Figs. 13A13D). However, during most of the mid-Oligocene (Biochrons P21aP21b), Atlantic City sequences are relatively thick and continuous, whereas sequences at Island Beach and Cape May are thin or absent, suggesting that the depositional center shifted to near Atlantic City. 
Deposition resumed at all three sites during the late Oligocene (Biochrons P22); however, the thickest sequences observed remained near Atlantic City. Miller and Sugarman (1995) suggested that increased sediment supply can cause local flexural subsidence. This process can explain the differential preservation of mid-Oligocene sequences. In contrast, Benson (1990) attributed the absence of upper Oligocene strata in the Lewes, DE well ( $30 \mathrm{~km}$ from Cape May; Fig. 13) to faulting and uplift. Further study will be needed to determine the cause of this abrupt change in depositional history between the Lewes well and the Cape May borehole.

Differential preservation of coastal plain sections (such as the mid-Oligocene) has been attributed to tectonics for some time. Owens et al. (Chapter 2, this volume) termed the progressive shifting in basin depocenters the "rolling basin" concept. Brown et al. (1972) suggested that coastal plain tectonics was caused by faulting of crustal blocks. Benson (1994) suggested that $\sim 250 \mathrm{~m}$ of shoaling occurred at Lewes, DE between the early Oligocene and the earliest Miocene (Fig. 1). He ascribed this by a combination of eustatics and faulting tectonics. However, we found no evidence for paleodepths greater than outer neritic at our nearby Cape May borehole. In contrast, we estimate $\sim 40-60 \mathrm{~m}$ of shallowing across the mid-Oligocene disconformity at Cape May (Fig. 4). Backtracking (Steckler and Watts, 1981) of Cape May and Atlantic City indicates that less than $50 \mathrm{~m}$ of differential subsidence can explain the stratal patterns (Miller et al., Chapter 27, this volume). Nevertheless, further studies of the Oligocene section between Island Beach and Lewes are needed to document fully the nature and cause of the mid-Oligocene tectonic change.

\section{Changes in Sedimentation and Sequence Architecture}

Large climatic changes may explain differences in sequence stratigraphic architecture between lower and upper Oligocene sequences. Lower Oligocene sequences are typically thinner than their upper Oligocene counterparts and are composed mainly of TSTs and truncated lower HSTs (the only exception is the $\mathrm{O} 2$ sequence at Island Beach, which has a thick HST). This is in sharp contrast to thick upper Oligocene sequences that contain thinner, less developed TSTs, and thick, extensive HSTs that include upper HSTs (e.g., glauconitic medium-to coarse-grained quartz sands facies).

The amplitude of sea-level change influences the relative distribution and thickness of the systems tracts within a sequence (Steckler et al., 1993). Increased amplitude would result in a thicker and more developed TST and the diminution of the HST within a sequence. For example, during the Pliocene-Pleistocene (a time of high-amplitude sea-level changes), New Jersey shelf sequences were relatively thin, composed almost entirely of TST, and contained only severely truncated HSTs (Carey et al., 1995). This pattern is reminiscent of lower Oligocene sequences in New Jersey, which are often thin and consist of TSTs and truncated HSTs. This implies that the sequence stratigraphic architecture for the early Oligocene in New Jersey was controlled by higher amplitude glacioeustatic changes. This agrees well with deep-sea benthic foraminiferal $\delta^{18} \mathrm{O}$ records, which suggest high-amplitude sea-level fluctuations (Zachos et al., 1996).

The preservation and architecture of lower vs. upper Oligocene sequences is also influenced by longer term changes in sediment supply on the New Jersey Margin (Miller et al., 1996b). These changes include the switch from carbonate ramp development during the Eocene to sediment starved shelves during the early Oligocene and prograding clinoforms during the ?late Oligocene to earliest Miocene (Miller et al., 1996b). The thin lower Oligocene glauconitic sequences are consistent with this pattern. The relatively thick clastic upper Oligocene deposits may represent the switch from the sediment starved shelfal deposits and the initiation of the prograding clinoforms. This suggests that a major increase in clastic sedimentation occurred in the late Oligocene ( 26-25 Ma) on the New Jersey Margin. Poag and Sevon (1989) observed that a dramatic increase in si-
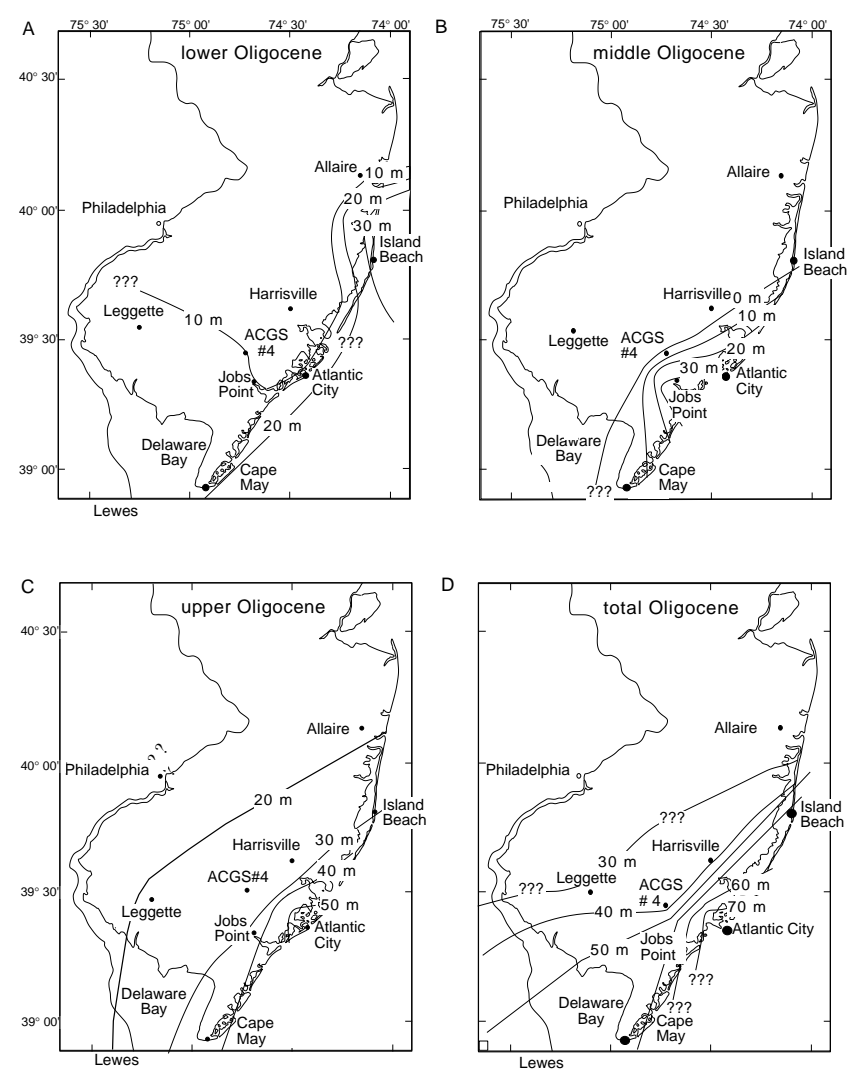

Figure 13. A. Isopach Map for the lower Oligocene (Biochrons P18 and P19), using data from Allaire, Island Beach, Atlantic City, Jobs Point, ACGS\#4, Leggette, Cape May, and Lewes wells. B. Isopach map for the mid-Oligocene (Biochrons P20-P21b), using data from Allaire, Island Beach, Atlantic City, Jobs Point, ACGS\#4, Leggette, Cape May, and Lewes wells. C. Isopach map for the upper Oligocene (Biochron P22), using data from Allaire, Island Beach, Atlantic City, Jobs Point, ACGS\#4, Leggette, Cape May, and Lewes wells. D. Isopach Map for the entire Oligocene, using data from Allaire, Island Beach, Atlantic City, Jobs Point, ACGS\#4, Leggette, Cape May, and Lewes wells.

liciclastic deposition began offshore in the Baltimore Canyon Trough about $25 \mathrm{Ma}$, agreeing well with our data.

Oligocene sequences display one depositional peculiarity: they contain abundant recycled glauconite. This recycled glauconite is observed in the HSTs (when preserved) of Oligocene sequences, but is rare to lacking in HSTs from other epochs. The $\delta^{18} \mathrm{O}$ records indicate that there were several Oligocene glaciations and deglaciations (Fig. 2; Miller et al., 1991). The rapid eustatic falls resulting from icevolume buildup allowed subaerial exposure and erosion of older Eocene and Cretaceous glauconitic sediments. The eroded glauconite was re-deposited in the HST during the Oligocene. Low sedimentation rates (10-20 m/m.y.) also indicate that the shelf was starved of siliciclastic input, favoring not only formation of in situ glauconite, but also the nondilution of detrital glauconite by other clastics.

\section{CONCLUSIONS}

A composite of the three Leg 150X New Jersey Coastal Plain boreholes indicates six Oligocene sequences (three lower Oligocene and three upper Oligocene). Six of seven Oligocene to lowermost Miocene sequence boundaries correlate to major $\delta^{18} \mathrm{O}$ increases, implying that the unconformities are glacioeustatically controlled. One 
additional sequence boundary correlates to a minor $\delta^{18} \mathrm{O}$ increase. Six third-order Oligocene eustatic cycles of Haq et al. (1987) correlate with the New Jersey Oligocene sequences. A sequence boundary observed at 28.3 Ma in New Jersey does not correlate with any sequence boundary in the Haq et al. (1987) inferred eustatic record; however, this sequence boundary correlates with a $\delta^{18} \mathrm{O}$ increase, suggesting that it is primarily a result of eustatic lowering. We conclude that Oligocene sequences were controlled primarily by eustasy, although sequence variations observed during the mid-Oligocene were influenced by local tectonics and sediment supply.

\section{ACKNOWLEDGMENTS}

We thank R. Benson, R.K. Olsson, and P. Sugarman for discussions. We thank R. Benson, and W. Poag for reviews and L. de Verteuil for his assistance and dinocyst data. This is supported by NSF Grants EAR92-18210 and EAR94-17108. This is a LDEO contribution.

\section{REFERENCES}

Bandy, O.L., 1964. General correlation of foraminiferal structure with environment. In Imbrie, J., and Newell, N.D. (Eds.), Approaches to Paleoecology: New York (Wiley and Sons), 75-90.

Benson, R.N., 1990. Geologic and hydrologic studies of the Oligocene-Pleistocene section near Lewes, Delaware. Delaware Geol. Surv. Rep., 48:134.

1994. Mid-Oligocene unconformity and faulting in the Atlantic coastal plain of Delaware correlated with uplift history of AppalachianLabrador and Bermuda Rises. Geol. Soc. Am. Abstr. Progr., 26:A-91.

Berggren, W.A., Kent, D.V., Swisher, C.C., III, and Aubry, M.-P., 1995. A revised Cenozoic geochronology and chronostratigraphy. In Berggren, W.A., Kent, D.V., Aubry, M.-P., and Hardenbol, J. (Eds.), Geochronology, Time Scales and Global Stratigraphic Correlation. Spec. Publ.Soc. Econ. Paleontol. Mineral., 54:129-212.

Boersma, A., 1984. A Handbook of Common Tertiary Uvigerina: Stony Point, NY (Microclimates Press).

Brown, P.M., Miller, J.A., and Swain, F.M., 1972. Structural and stratigraphic framework, and spatial distribution of permeability of the Atlantic Coastal plain, North Carolina to New York: U.S. Geological Survey Professional Paper 175-A, 1-50.

Butt, A.A., 1966. Late Oligocene Foraminifera from Escornebeou, SW France: Utrecht (Schotanus and Jens).

Cande, S.C., and Kent, D.V., 1992. A new geomagnetic polarity time scale for the Late Cretaceous and Cenozoic. J. Geophys. Res., 97:13,91713,951 .

Carey, J.S., Sheridan, R.E., and Ashley, G.M., 1995. Late Pleistocene sequence stratigraphy of the New Jersey continental shelf. AAPG 1995 Annu. Conv., 4:15A.

Cushman, J.A., and Cahill, E.D., 1933. Foraminifera of the coastal plain of the Eastern U.S. Geol. Surv. Prof. Pap. U.S., 175A.

Cushman, J.A., and Stainforth, R.M., 1945. The foraminifera of the Cipero Marl Formation of Trinidad, British West Indies. Spec. Publ.—Cushman Lab., 14:1-75.

Donovan, D.T., and Jones, E.J.W., 1979. Causes of world-wide changes in sea-level. J. Geol. Soc. London, 136:187-192.

Haq, B.U., Hardenbol, J., and Vail, P.R., 1987. Chronology of fluctuating sea levels since the Triassic. Science, 235:1156-1167.

Haq, B.U., Hardenbol, J., and Vail, P.R., 1988. Mesozoic and Cenozoic chronostratigraphy and cycles of sea-level change. In Wilgus, C.K., Hastings, B.S., Kendall, C.G.St.C., Posamentier, H.W., Ross, C.A., and Van Wagoner, J.C. (Eds.), Sea-Level Changes-An Integrated Approach. Spec. Publ.-Soc. Econ. Paleontol. Mineral., 42:72-108.

Kafescioglu, I.A., 1975. A quantitative distribution of Foraminifera on the continental shelf and uppermost slope off Massachusetts. Micropaleontology, 21:261-305.

Kidwell, S.M., 1989. Stratigraphic condensation of marine transgressive records: origin of major shell deposits in the Miocene of Maryland. $J$. Geol., 97:1-24.

Lamb, J.L., and Miller, T.H., 1984. Stratigraphic significance of Uvigerinid foraminifera in the Western Hemisphere. Univ. Kansas Paleontol. Contrib. Art., 66:1-98.
Loeblich, A.R., and Tappan, H., 1964. Sarcodina. In Moore, R.C. (Ed.) Treatise on Invertebrate Paleontology, Pt. C, Protista 2 (vols. 1 and 2): Boulder (Geol. Soc. Am. and Univ. Kansas Press).

Loutit, T.S., Hardenbol, J., Vail, P.R. and Baum, G.R., 1988. Condensed sections: the key to age determination and correlation of continental margin sequences. In Wilgus, C.K., Hastings, B.S., Ross, C.A., Posamentier, H.W., Van Wagoner, J., and Kendall, C.G.St.C. (Eds.), Sea-Level Changes: An Integrated Approach. Spec. Publ.-Soc. Econ. Paleontol. Mineral., 42:183-213.

McRae, S.G., 1972. Glauconite. Earth-Sci. Rev., 8:397-440.

Miller, K.G., et al., 1994. Proc. ODP Init. Repts., 150X: College Station, TX (Ocean Drilling Program).

, 1996a. Proc. ODP, Init. Repts., 150X (Suppl.): College Station, TX (Ocean Drilling Program).

Miller, K.G., and Fairbanks, R.G., 1985. Oligocene to Miocene carbon isotope cycles and abyssal circulation changes. In Sundquist, E.J., and Broecker, W.S. (Eds.), The Carbon Cycle and Atmospheric $\mathrm{CO}_{2}$ : Natural Variations, Archean to Present. Geophys. Monogr., Am. Geophys. Union, 32:469-486.

Miller, K.G., Fairbanks, R.G., and Mountain, G.S., 1987. Tertiary oxygen isotope synthesis, sea-level history, and continental margin erosion. Paleoceanography, 2:1-19.

Miller, K.G., Feigenson, M.D., Kent, D.V., and Olsson, R.K., 1988. Upper Eocene to Oligocene isotope $\left({ }^{87} \mathrm{Sr} /{ }^{86} \mathrm{Sr}, \delta^{18} \mathrm{O}, \delta^{13} \mathrm{C}\right)$ standard section, Deep Sea Drilling Project Site 522. Paleoceanography, 3:223-233.

Miller, K.G., Kent, D.V., Brower, A.N., Bybell, L.M., Feigenson, M.D., Olsson, R.K., and Poore, R.Z., 1990. Eocene-Oligocene sea-level changes on the New Jersey coastal plain linked to the deep-sea record. Geol. Soc. Am. Bull., 102:331-339.

Miller, K.G., Liu, C., and Feigenson, M.D., 1996b. Oligocene to middle Miocene Sr-isotopic stratigraphy of the New Jersey continental slope. In Mountain, G.S., Miller, K.G., Blum, P., Poag, C.W., and Twichell, D.C. (Eds.), Proc. ODP, Sci. Results, 150: College Station, TX (Ocean Drilling Program), 97-114.

Miller, K.G., and Lohmann, G.P., 1982. Environmental distribution of Recent benthic foraminifera on the northeast United States continental slope. Geol. Soc. Am. Bull., 93:200-206.

Miller, K.G., and Sugarman, P.J., 1995. Correlating Miocene sequences in onshore New Jersey boreholes (ODP Leg 150X) with global $\delta^{18} \mathrm{O}$ and Maryland outcrops. Geology, 23:747-750.

Miller, K.G., Thompson, P.T., and Kent, D.V., 1993. Integrated late EoceneOligocene stratigraphy of the Alabama coastal plain: correlation of hiatuses and stratal surfaces to glacioeustatic lowerings. Paleoceanography, 8:313-331.

Miller, K.G., Wright, J.D., and Fairbanks, R.G., 1991. Unlocking the ice house: Oligocene-Miocene oxygen isotopes, eustasy, and margin erosion. J. Geophys. Res., 96:6829-6848.

Olsson, R.K., 1991. Cretaceous to Eocene sea-level fluctuations on the New Jersey margin. Sediment. Geol., 70:195-208.

Olsson, R.K., Miller, K.G., and Ungrady, T.E., 1980. Late Oligocene transgression of middle Atlantic coastal plain. Geology, 8:549-554.

Oslick, J.S., Miller, K.G., and Feigenson, M.D., 1994. Oligocene-Miocene Strontium isotopes: stratigraphic revisions and correlations to an inferred glacioeustatic record. Paleoceanography, 9:427-443.

Owens, J.P., Bybell, L.M., Paulachok, G., Ager, T.A., Gonzalez, V.M., and Sugarman, P.J., 1988. Stratigraphy of the Tertiary sediments in a $945-$ foot-deep core hole near Mays Landing in the southeastern New Jersey Coastal Plain. Geol. Surv. Prof. Pap. U.S., 1484.

Owens, J.P., and Sohl, N.F., 1969. Shelf and deltaic paleoenvironments in the Cretaceous-Tertiary formations of the New Jersey Coastal Plain. In Subitzky, S. (Ed.), Geology of Selected Areas in New Jersey and Eastern Pennsylvania and Guidebook of Excursions: New Brunswick, NJ (Rutgers Univ. Press), 235-278.

Parker, F.L., 1954. Distribution of the Foraminifera in the northeastern Gulf of Mexico. Bull. Mus. Comp. Zool., 111:453-588.

Pekar, S.F., 1995. New Jersey Oligocene sequences recorded at the Leg 150X boreholes (Cape May, Atlantic City, and Island Beach) [Master's thesis]. Rutgers Univ., Piscataway, NJ.

Pekar, S.F., and Miller, K.G., 1996. New Jersey Oligocene "Icehouse" sequences (ODP Leg 150X) correlated with global $\delta^{18} \mathrm{O}$ and Exxon eustatic records. Geology, 24:567-570.

Phleger, F.B., and Parker, F.L., 1951. Ecology of foraminifera, Northwest Gulf of Mexico, Part II. Foraminifera species. Mem.-Geol. Soc. Am., 46:1-64.

Poag, C.W., 1981. Ecologic Atlas of Benthic Foraminifera of the Gulf of Mexico: Woods Hole (Marine Science International). 
Poag, C.W., and Sevon, W.D., 1989. A record of Appalachian denudation in postrift Mesozoic and Cenozoic sedimentary deposits of the U.S. middle Atlantic continental margin. Geomorphology, 2:119-157.

Poore, R.Z., and Bybell, L.M., 1988. Eocene to Miocene biostratigraphy of New Jersey core ACGS \#4: implications for regional stratigraphy. Geol. Surv. Prof. Pap. U.S., 1829.

Posamentier, H.W., Jervey, M.T., and Vail, P.R., 1988. Eustatic controls on clastic deposition, I. Conceptual framework. In Wilgus, C.K., Hastings, B.S., Ross, C.A., Posamentier, H.W., Van Wagoner, J., and Kendall, C.G.St.C. (Eds.), Sea-Level Changes: An Integrated Approach. Spec. Publ.-Soc. Econ. Paleontol. Mineral., 42:109-124.

Reilly, T.J., Miller, K.G., Feigenson, M.D., 1996. Sr-isotopic changes during the late Eocene to Oligocene: A revised record from Site 522, eastern South Atlantic. Geol. Soc. Am. Abstr. Prog., A426-A427.

Renz, H.H., 1948. Stratigraphy and fauna of the Agua Salada Group, State of Falcón, Venezuela. Mem.-Geol. Soc. Am., 32:1-219.

Schnitker, D., 1970. Upper Miocene Foraminifera From Near Grimeland, Pitt County, North Carolina. North Carolina Dept. Conservation and Development.

Schnitker, D., 1971. Distribution of foraminifera on the North Carolina Continental Shelf. Tulane Stud. Geol. Paleont., 8:169-215.

Sen Gupta, B.K., 1971. The benthonic foraminifera of the tail of the Grand Banks. Micropaleontology, 17:69-98.

Sen Gupta, B.K., and Kilborne, R.T., 1976. Depth distribution of benthic foraminifera on the Georgia continental shelf. Spec. Publ.-1st Int. Symp. Benthic Foraminifera Continental Margin, Maritime Sediments, 1:2538.

Shackleton, N.J., and Kennett, J.P., 1975. Paleotemperature history of the Cenozoic and the initiation of Antarctic glaciation: oxygen and carbon isotope analyses in DSDP Sites 277, 279, and 281. In Kennett, J.P., Houtz, R.E., et al., Init. Repts. DSDP, 29: Washington (U.S. Govt. Printing Office), 743-755.

Shackleton, N.J., and Opdyke, N.D., 1973. Oxygen isotope and paleomagnetic stratigraphy of equatorial Pacific core V28-238: oxygen isotope temperatures and ice volumes on a $10^{5}$ year and $10^{6}$ year scale. Quat. Res., 3:39-55.

Smith, P.B., 1964. Ecology of benthonic species. Geol. Surv. Prof. Pap. U.S., 429-B.

Steckler, M.S., Reynolds, D.J., Coakley, B.J., Swift, B.A., and Jarrard, R., 1993. Modelling passive margin sequence stratigraphy. In Posamentier,
H.W., Summerhayes, C.P., Haq, B.U., and Allen, G.P. (Eds.), Sequence Stratigraphy and Facies Associations. Spec. Publ. Int. Assoc. Sedimentol., 18:19-41.

Steckler, M.S., and Watts, A.B., 1981. Subsidence history and tectonics of Atlantic type continental margins. Am. Geophys. Union Geodyn. Ser., 6:184-196.

Sugarman, P.J., Miller, K.G., Owens, J.P., and Feigenson, M.D., 1993. Strontium isotope and sequence stratigraphy of the Miocene Kirkwood Formation, southern New Jersey. Geol. Soc. Am. Bull., 105:423-436.

Sugarman, P.J., Miller, K.G., Bukry, D., and Feigenson, M.D., 1995. Uppermost Campanian-Maestrichtian Strontium isotopic, biostratigraphic, and sequence stratigraphic framework of the New Jersey Coastal Plain. Geol. Soc. Am. Bull., 107:19-37.

Toulmin, L.D., 1941. Eocene smaller foraminifera from the Salt Mountain Limestone of Alabama. J. Paleontol., 15:567-611.

Vail, P.R., and Mitchum, R.M., Jr., 1977. Seismic stratigraphy and global changes of sea level, Part 1. Overview. In Payton, C.E. (Ed.), Seismic Stratigraphy: Applications to Hydrocarbon Exploration. AAPG Mem., 26:51-52.

Van Morkhoven, F.P.C.M., Berggren, W.A., and Edwards, A.S., 1986. Cenozoic Cosmopolitan Deep-Water Benthic Foraminifera. Bull. Cent. Rech. Explor-Prod. Elf-Aquitaine, Mem. 11.

Walton, W.R., 1964. Recent foraminiferal ecology and paleoecology. In Imbrie, J., and Newell, N.D. (Eds.), Approaches to Paleoecology: New York (Wiley), 151-237.

Wood, K.C., Miller, K.G., and Lohmann, G.P., 1985. Middle Eocene to Oligocene benthic foraminifera from the Oceanic Formation, Barbados. Micropaleontology, 31:181-196.

Zachos, J.C., Quinn, T.M., and Salamy, S., 1996. High resolution $\left(10^{4} \mathrm{yr}\right)$ deep-sea foraminiferal stable isotope records of the earliest Oligocene climate transition. Paleoceanography, 11:251-266.

Zachos, J.C., Stott, L.D., and Lohmann, K.C., 1994. Evolution of early Cenozoic marine temperatures. Paleoceanography, 9:353-387.

Date of initial receipt: 1 February 1996

Date of acceptance: 23 September 1996 Ms 150XSR-314 